\title{
23. PALEOCLIMATIC EVOLUTION OF SANTA BARBARA BASIN DURING THE LAST 20 K.Y.: MARINE EVIDENCE FROM HOLE 893A ${ }^{1}$
}

\author{
J.P. Kennett ${ }^{2}$ and B.L. Ingram ${ }^{3}$
}

\begin{abstract}
The paleoclimatic record for the last $20 \mathrm{k} . \mathrm{y}$. has been examined within a detailed radiocarbon age framework for Hole 893A. Santa Barbara Basin. California, using benthic and planktonic foraminiferal oxygen isotopes and assemblage changes in planktonic foraminifers. The last deglaciation is recorded as two steps (Terminations IA and IB) separated by a warm pause, correlative with the Bølling/Allerød Interstadial (15.2 to $13 \mathrm{ka}$ ), followed by Younger Dryas cooling ( 13 to $11.1 \mathrm{ka})$. This, in turn, was followed by the warmth of the Holocene. Changes in the planktonic foraminiferal assemblage suggest that average sea-surface temperatures in the basin increased from $\sim 7^{\circ} \mathrm{C}$ during the last glacial maximum to $\sim 15^{\circ} \mathrm{C}$ during the late Holocene, an estimated change larger than shown in earlier work.

Hole 893A consists of alternating laminated and nonlaminated (massive) sediment intervals. Laminated intervals were deposited at times of low dissolved oxygen levels in the basin that precluded support of an active benthos. Massive intervals resulted from bioturbation associated with more oxygenated waters. The basin was relatively well ventilated during the glacial to near-glacial intervals (last glacial maximum and Younger Dryas cooling) and poorly ventilated during warm intervals (Bølling/Allerød Interstadial and Holocene during the last 11 k.y.). Thus, the sequence records oscillations between two fundamentally different states, one marked by bottom waters with low oxygen content associated with warm intervals, the other with relatively oxygenated waters associated with cold intervals.

We interpret these oscillations in sediment facies to reflect changes in the source of intermediate waters, with a greater proportion of oxygen-rich waters originating from a more proximal source during cooler intervals compared with a distal source of oxygen-poor waters during warmer intervals, including the present day. The stratigraphic records examined here strongly indicate that, as in the North Atlantic, fundamental changes occurred in North Pacific intermediate water circulation during the latest Quaternary. These were closely synchronized with global climate change and with paleoceanographic events in the North Atlantic. It is possible that changing strength of oceanic conveyor circulation, currently transporting waters from the North Atlantic to the North Pacific, may have in part caused changes in oxygen content of upper intermediate waters near the coast of North America, including the Santa Barbara Basin. Alternatively, the inter-ocean paleoceanographic changes were linked directly through global climate change transmitted through the atmosphere rather than through changes in the strength of the oceanic conveyor. In this case, severe cooling during the last glacial maximum and the Younger Dryas episode led to the production of intermediate waters at high latitudes in the Pacific Ocean that influenced Santa Barbara Basin ventilation. Of proximal origin, these were young, well oxygenated waters. A third, more likely, hypothesis is that both factors in combination played a role in influencing the ventilation history of the basin. This investigation indicates the existence of tight coupling between changes in the atmosphere-ocean-cryosphere during the latest Quaternary.
\end{abstract}

\section{INTRODUCTION}

Ocean Drilling Program Hole 893A contains a 196.5-m-thick late Quaternary ( 160 ka to present day) sedimentary sequence from Santa Barbara Basin, Southern California. Paleoenvironmental history is interpreted using changes in oxygen isotopes, planktonic foraminiferal assemblages, and physical characteristics of sediments. Site 893 is located at $34^{\circ} 17.25^{\prime} \mathrm{N}, 120^{\circ} 02.2^{\prime} \mathrm{W}$, in Santa Barbara Basin, 20 $\mathrm{km}$ south of the Santa Barbara coastline at a water depth of $576.5 \mathrm{~m}$ (Fig. 1A; Kennett, Baldauf, et al., 1994). Site 893 is the first continuously cored sequence of latest Quaternary age (older than Holocene) from the Southern California Borderland Province. The province is made up of a number of semi-enclosed tectonic basins marked by limited deepwater exchange with the Pacific Ocean. This partial isolation contributes to a severe reduction in oxygen concentrations in

' Kennet, J.P.. Baldauf, J.G., and Lyle, M. (Eds.), 1995. Proc, ODP, Sci, Results, 146 (Pt. 2): College Station, TX (Ocean Drilling Program).

${ }^{2}$ Marine Science Institute and Department of Geological Sciences, University of California Santa Barbara, Santa Barbara, CA 93106. U.S.A.

'Department of Geology and Geophysics, University of California Berkeley. Berkeley, CA 94720 . U.S.A. bottom waters of Santa Barbara Basin from $~ 500 \mathrm{~m}$ to $600 \mathrm{~m}$ (the maximum depth of the basin), leading to the accumulation of organic carbon and anoxic muds (Emery, 1960). Sediments have also accumulated rapidly $(\sim 160 \mathrm{~cm} / 1000$ years $)$ with minimal biological disturbance. Benthic and planktonic foraminifers occur in sufficient abundance to provide an important opportunity for high-resolution late Quaternary paleoclimatic/paleoceanographic investigations. Sediments cored at Site 893 offer one of the few sites in the world ocean with such high potential for high-resolution studies. It is possible to resolve decadal paleoclimatic changes and even interannual to annual climatic change in those parts of the sequence where annual laminae are preserved.

In this contribution we present and discuss the isotopic and faunal record of paleoclimatic change in Santa Barbara Basin during the last deglaciation from the glacial maximum ( $20 \mathrm{ka}$ ) to the Holocene interglacial within the context of global climatic and oceanographic changes. Santa Barbara Basin is especially valuable for such an investigation because of its location close to the continental margin of the northeast Pacific where upwelling of intermediate waters occurs. The margins of the modern north and northeast Pacific are marked by intense upwelling of intermediate waters, some proportion of which appears to have originated as North Atlantic Deep Water (NADW) at high latitudes of the North Atlantic and flowed within 

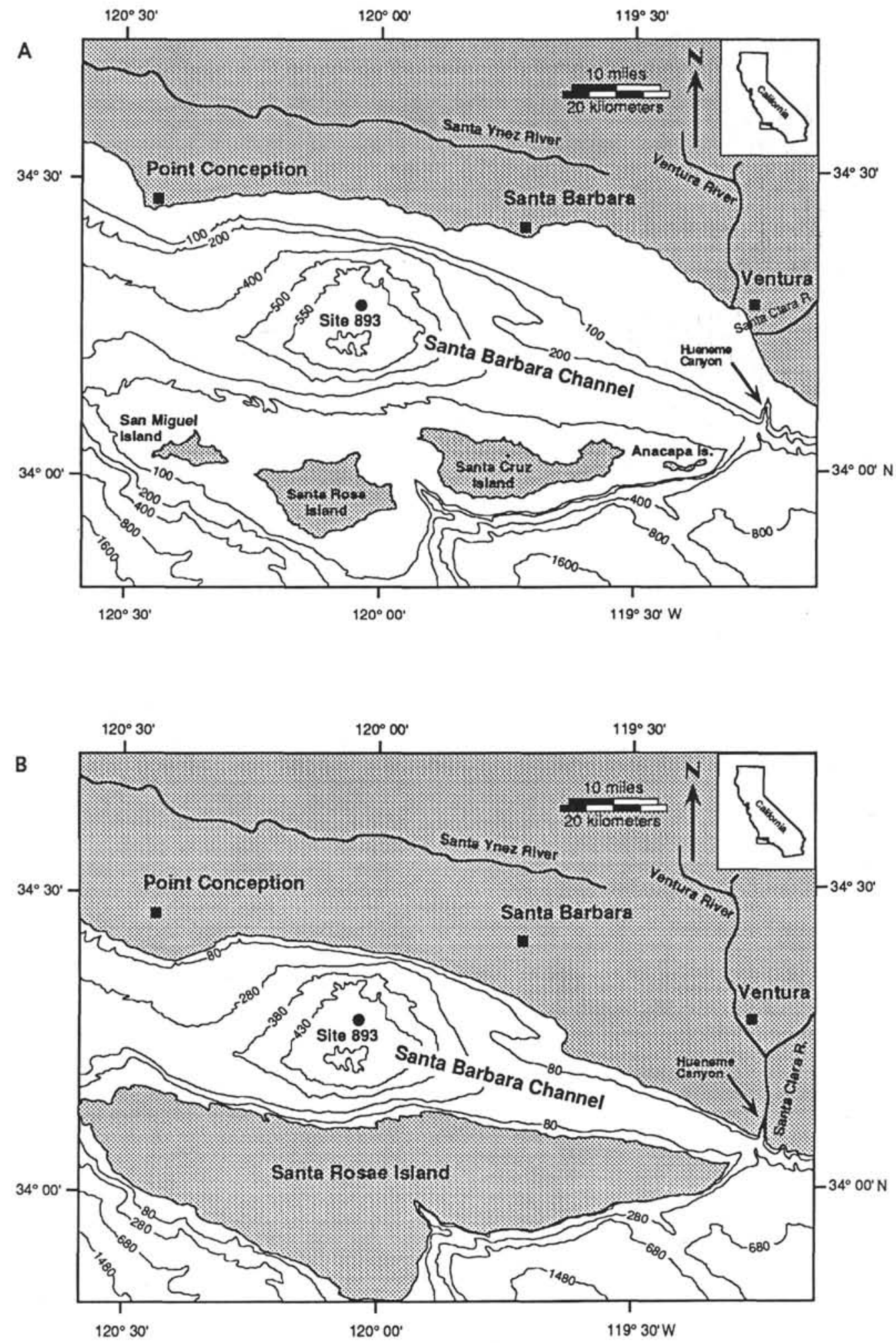

Figure 1. Location of Site 893 in Santa Barbara Basin. A. Present-day (interglacial) physiography. B. Last glacial maximum (18 ka) physiography, when sea level was $120 \mathrm{~m}$ lower than at present.

the so-called oceanic conveyor to the North Pacific (Broecker and Denton, 1989). Oxygen concentrations decrease during both transit and aging of waters within the conveyor because of biological metabolism and oxidation of organic matter (Broecker and Peng, 1982). Modern intermediate waters advecting upward near the coast of California contain low concentrations of oxygen. Oxygen is further re- duced by upward advection through the oxygen minimum zone at upper bathyal depths. This oxygen-poor water flows over the sill into Santa Barbara Basin (Fig. 2). The small supplies of oxygen entering the basin are further depleted through the oxidation of abundant organic material derived from highly productive surface waters. In the modern basin, these processes collectively result in the presence of 


\section{Dissolved Oxygen} $\mathrm{mL} / \mathrm{L}$

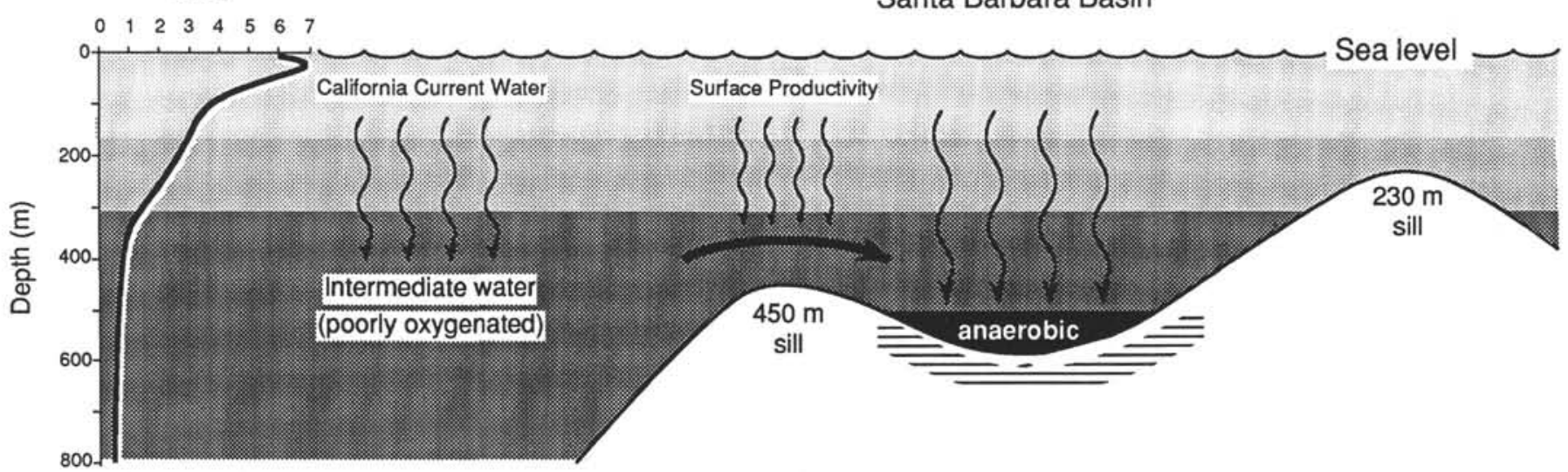

Figure 2. Schematic diagram showing modern (interglacial) distribution of water masses in the region of Santa Barbara Basin and changes in dissolved oxygen in the water column. Darker shades of water masses reflect decreased oxygen content. Note dysaerobic (suboxic) bottom waters in center of Santa Barbara Basin. Zone of high biological productivity also extends seaward (eastward) of the 450-m sill, within the California Current.

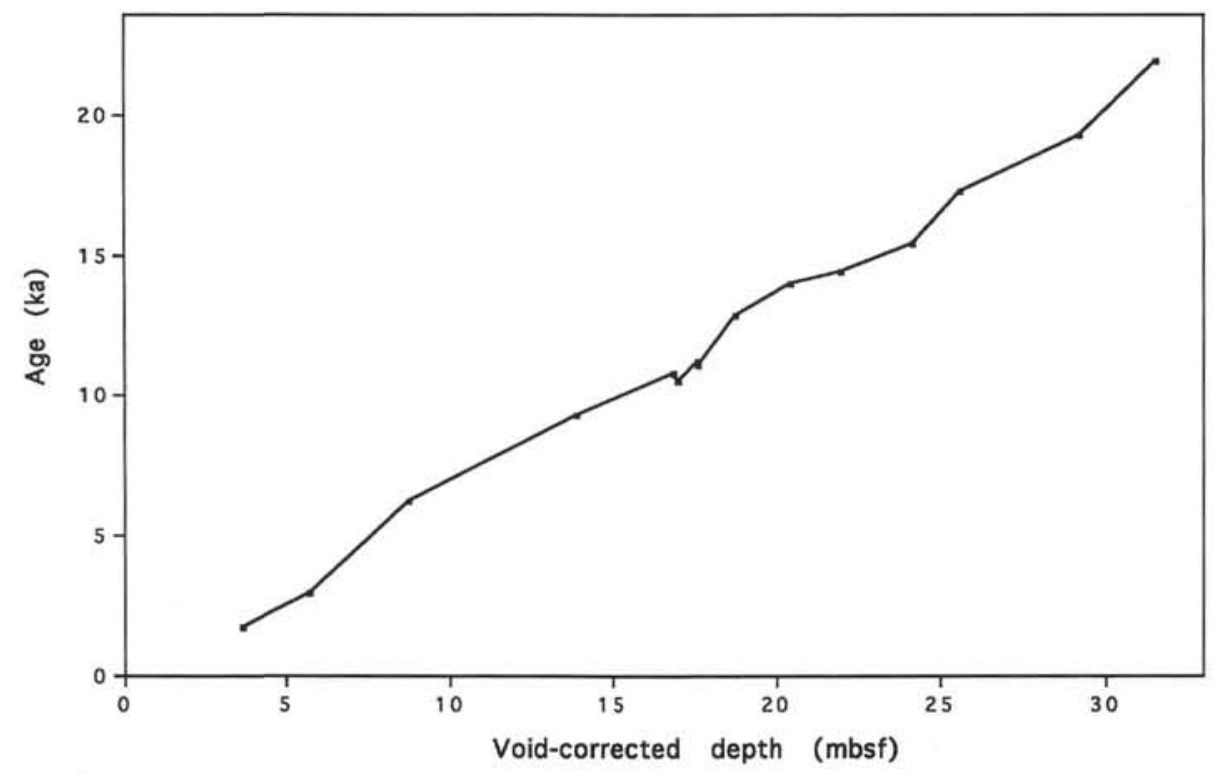

Figure 3. Calendar ages of planktonic foraminiferal samples plotted against corrected depth (mbsf) in the upper $32 \mathrm{~m}$ of Hole $893 \mathrm{~A}$. Calendar ages are derived from corrected accelerator mass spectrometry radiocarbon ages. Steps used for calibration and correction of radiocarbon ages are outlined by Ingram and Kennett (this volume) and in the text. Sample depths corrected for all gaps (voids) resulting from sediment displacement due to gas expansion (Rack and Merrill, this volume).

suboxic $(<0.1 \mathrm{~mL} / \mathrm{L}$ oxygen $)$ bottom waters deeper than $\sim 475 \mathrm{~m}$. Reduction in deep water oxygen concentrations is so severe that Santa Barbara Basin is the only basin in the California Borderland Province that exhibits persistent annual varves through most of the Holocene.

Prior to our study, the only high-resolution North Pacific record examined near the end of deep water flow within the conveyor is that of Keigwin and Jones (1990), who examined a drilled sediment sequence in Guaymas Basin, Gulf of California. Such records are critical for comparison with the paleoceanographic changes in the North Atlantic, near the beginning of conveyor flow.

Sediments drilled at Hole 893A consist of a sequence of laminated to nonlaminated intervals. Laminations were deposited during times marked by an absence of burrowing organisms when bottom waters contained low oxygen concentrations, whereas fully homogenized (massive or nonlaminated) intervals were deposited during more highly oxygenated conditions in the basin. The sediment sequence of Hole 893A exhibits two broadly similar sedimentary sequences that consist in each case of a lower, intermittently laminated interval passing upward, with decreasing abundance of laminations, into a relatively thin homogeneous (massive) interval. This homogeneous interval is then succeeded abruptly by a thin interval of relatively continuous, well-laminated sediment (Kennett, Baldauf, et al., 1994). The sequence at Hole $893 \mathrm{~A}$ represents one complete and two partial cycles reflecting progressive dominance of oxygenated basin waters, culminating in a period of sustained basin oxygenation. Preliminary studies suggest that these sediment cycles, expressed by the 
Table 1. Radiocarbon dates and corrected calendar year ages for planktonic foraminiferal samples used to construct chronological framework (see Fig. 3) for the upper $\sim 32 \mathrm{~m}$ in Hole 893A, Santa Barbara Basin (Ingram and Kennett, this volume).

\begin{tabular}{|c|c|c|c|c|}
\hline $\begin{array}{l}\text { Core, section, } \\
\text { interval }(\mathrm{cm})\end{array}$ & $\begin{array}{c}\text { Raw depth } \\
\text { (mbsf) }\end{array}$ & $\begin{array}{l}\text { Corrected } \\
\text { depth } \\
\text { (mbsf) }\end{array}$ & $\begin{array}{l}\text { Planktonic } \\
\text { age } \\
\text { (ka) }\end{array}$ & $\begin{array}{l}\text { Corrected } \\
\text { age (ka) }\end{array}$ \\
\hline \multicolumn{5}{|l|}{$146-893 \mathrm{~A}$} \\
\hline IH-1, 55-57 & & 1.55 & 1.85 & 0.95 \\
\hline $1 \mathrm{H}-3,63-66$ & 3.63 & 3.63 & 2.52 & 1.67 \\
\hline $1 \mathrm{H}-4,117-119$ & 5.67 & 5.67 & 3.55 & 2.78 \\
\hline $2 \mathrm{H}-1,55-57$ & & 7.04 & 4.80 & 4.51 \\
\hline $2 \mathrm{H}-2,71-73$ & 8.71 & 8.71 & 6.20 & 6.19 \\
\hline $2 \mathrm{H}-4,105-107$ & & 11.77 & 8.23 & 8.23 \\
\hline $2 \mathrm{H}-6,48-50$ & 13.97 & 13.91 & 9.05 & 9.34 \\
\hline $2 \mathrm{H}-6,55-57$ & & 13.98 & 9.18 & 9.40 \\
\hline $3 \mathrm{H}-1,6-8$ & & 16.06 & 10.16 & 10.65 \\
\hline $3 \mathrm{H}-1,87-90$ & 16.87 & 16.84 & 10.28 & 10.79 \\
\hline $3 \mathrm{H}-1,98-102$ & 16.99 & 16.96 & 10.17 & 10.47 \\
\hline $3 \mathrm{H}-2,11-13$ & 17.58 & 17.58 & 10.72 & 11.31 \\
\hline $3 \mathrm{H}-2,13-16$ & 17.60 & 17.60 & 10.63 & 11.06 \\
\hline $3 \mathrm{H}-2,113-115$ & & 18.60 & 11.18 & 12.00 \\
\hline $3 \mathrm{H}-2,128-130$ & 18.75 & 18.75 & 11.07 & 11.86 \\
\hline $3 \mathrm{H}-3,112-115$ & & 20.05 & 11.83 & 12.80 \\
\hline $3 \mathrm{H}-3,147-149$ & 20.44 & 20.40 & 11.83 & 12.99 \\
\hline $3 \mathrm{H}-5,9-12$ & 21.94 & 21.94 & 12.35 & 13.45 \\
\hline $3 \mathrm{H}-6,96-99$ & 24.17 & 24.12 & 13.13 & 14.41 \\
\hline $4 \mathrm{H}-1,8-11$ & 25.58 & 25.58 & 14.63 & 16.27 \\
\hline $4 \mathrm{H}-2,5-7$ & & 26.80 & 15.21 & 16.99 \\
\hline $4 \mathrm{H}-3,57-60$ & & 28.73 & 15.72 & 17.63 \\
\hline $4 \mathrm{H}-4,3-5$ & 29.61 & 29.21 & 16.26 & 18.29 \\
\hline $4 \mathrm{H}-4,90-93$ & & 30.34 & 16.82 & 18.99 \\
\hline $4 \mathrm{H}-5,57-60$ & & 31.39 & 17.41 & 19.72 \\
\hline $4 \mathrm{H}-5,73-75$ & 31.55 & 31.52 & 18.38 & 20.92 \\
\hline $5 \mathrm{H}-7,11-14$ & & 43.18 & 25.47 & 29.72 \\
\hline
\end{tabular}

changing strength of laminations, correspond closely with glacial/interglacial oscillations (Kennett, Baldauf, et al., 1994).

A number of hypotheses have been presented to account for the changing basinal oxygenation concentrations (Kennett, Baldauf, et al., 1994). The most popular of these suggests that changes in oxygen concentrations of intermediate waters from the Pacific advecting into Santa Barbara Basin during the late Quaternary were the primary control of the oxygenation-dysaerobia cycles recorded in the basinal sediments. Under this hypothesis, laminated intervals in the basin were deposited when low-oxygen intermediate waters flowed into the basin. Massive intervals, in contrast, were deposited when intermediate waters with higher oxygen concentrations flowed into the basin. A primary goal of this study was to develop detailed stratigraphic relationships between climatic change and the degree of oxygenation of Santa Barbara Basin for the last 20 k.y., in an attempt to test hypotheses that explain the ventilation changes in Santa Barbara Basin.

\section{OCEANOGRAPHIC SETTING}

The Santa Barbara Basin is ideally located to amplify global climate changes that occurred during the Quaternary. The dominant hydrographic features of Santa Barbara Basin are the southwardflowing California Current and related countercurrents (Hickey, 1992). The character and distribution of the cold California Current and nearshore warmer countercurrent (Davidson Current) are determined by ocean-atmosphere interactions over broad areas of the $\mathrm{Pa}$ cific Ocean (Douglas, 1981). A dominant feature of modern surface circulation in Santa Barbara Basin is a semipermanent cyclonic gyre that incorporates water from both the northwest and southeast. In present-day Santa Barbara Basin, there are no important effects upon surface water salinity by fresh water runoff from the nearby land masses (Fig. 1). Rivers have relatively little effect on the surface ocean environment in this semiarid region. Interpretations based on the late Quaternary pollen record in Hole 893A suggest that there was little difference in precipitation during glacial times compared with the present day (Heusser, this volume).

Seasonal variations in the California Current system are primarily controlled by changes in wind strength and direction. Northerly winds are generally strongest between April and August (spring and summer), causing strong flow of the cold California Current towards the south, and weak cyclonic flow into Santa Barbara Basin. Conversely, from December to February, when the northerly winds weaken, the Davidson Current is stronger and a net poleward surface transport occurs along the coast (Pisias, 1978). Seasonal changes in the strength and direction of the winds influence the intensity of upwelling near Point Conception and, in turn, affect the biological productivity in Santa Barbara Basin. Strong upwelling episodes occur from late spring to early summer. Individual upwelling episodes, lasting up to three weeks, vary according to the strength of the northerly winds (Bakun, 1975; McGowan, 1984; Eppley, 1986; Atkinson et al., 1986). The upwelled water is cold, oxygen-poor, and nutrient-rich in comparison with surface waters. The upwelling of cold waters during summer and the increased northward flow of the relatively warm Davidson Current in winter reduces the annual temperature range in surface waters, although this is still high at $12^{\circ} \mathrm{C}$ (Pisias, 1979). Periods of intensification of the Davidson Current are related to El Niño Southern Oscillation (ENSO) events that affect the entire eastern Pacific and typically occur at intervals of $\sim 5$ to $7 \mathrm{yr}$ (Enfield and Allen, 1980; Douglas, 1981). In the region of Santa Barbara Basin, these warm events coincide with episodes of decreased plankton productivity and reduced southerly flow of the California Current (Lange et al., 1987). The warmer events are often associated with anomalously high rainfall in Southern California (Namias, 1969).

Significantly, different boundary conditions existed in Santa Barbara Basin during the last glacial maximum. As a result of a drop in sea level of $121 \mathrm{~m}$ (Fairbanks, 1989), the channel was transformed into a narrow, sheltered body of water with more restricted circulation with the open Pacific Ocean (Fig. 1B). Strong restriction of the Anacapa Channel to the east of the basin would have reduced flow of any warm countercurrent (similar to the modern Davidson Current) into the Santa Barbara Basin from the south. At the same time, previous work has shown a strengthening of the influence of the California Current occurred in the California Borderland Province and associated major cooling of surface waters (Bandy,1968). By 12 ka during the Younger Dryas cool interval, sea level had risen to $\sim 60 \mathrm{~m}$ below present (Fairbanks, 1989) with associated widening of the Santa Barbara Channel region.

\section{PREVIOUS PALEOCLIMATIC STUDIES}

The latest Quaternary (20 k.y. to present day) paleoclimatic record of the northeast Pacific region has been examined by a number of earlier investigators (for example, Moore, 1973; Lyle et al., 1992; Sancetta et al., 1992; Heusser and Shackleton, 1979; Gardner et al., 1988; Mathewes et al., 1993) although the stratigraphic resolution of their data was lower than that presented here. We have examined, at high stratigraphic resolution, the latest Quaternary from the last glacial maximum to the present day (last 20 k.y.) in Santa Barbara Basin, northeast Pacific. Previous Quaternary paleoclimatic studies of Santa Barbara Basin were limited to the Holocene ( $9 \mathrm{ka})$. Of these Holocene studies, only two focused on paleoclimatic records on time scales of 1000 years or greater. Pisias $(1978 ; 1979)$ documented a paleoclimatic-paleoceanographic record of radiolarian-based sea-surface temperatures for the past 8000 years. This study suggested a history of significant paleoclimatic/paleoceanographic changes during the Holocene. Heusser (1978) documented Holocene terrestrial climate changes based on pollen and spores in a core from Santa Barbara Basin. This work indicates that the climate in the area from 8000 to $5400 \mathrm{ka}$ was dominantly warm subtropical and humid. Warm sea- 
surface temperatures, increased rainfall, and reduced southerly flow of the California Current indicated by these studies suggest a prolonged period of ENSO-like conditions. Since $5400 \mathrm{ka}$, the area has undergone major paleoclimatic fluctuations including a strengthening of the California Current system (Pisias, 1978).

A number of other investigations of Santa Barbara Basin sediment cores have dealt with the paleoclimatic history at high-resolution within the last three hundred years (Soutar and Crill, 1977; Weinheimer et al., 1986; Schimmelmann and Tegner, 1991). Dunbar (1983) produced a high-resolution planktonic foraminiferal (Globigerina bulloides) oxygen isotopic record for the last 230 years from a box core. This record closely correlates with the historical record of sea-surface temperature in the region since 1870. The amplitude of the oxygen isotopic signal is large $(1.5 \%)$ and partly reflects the large temporal and seasonal variability of sea-surface temperatures caused by upwelling and ENSO events. However, Dunbar (1983) noted that the isotopic range is greater than expected from historical temperature records, being amplified by seasonal and/or annual differential production of $G$. bulloides.

Earlier work of most significance to our study is that of Keigwin and Jones (1990), who described the stable isotope stratigraphy in a sediment core exhibiting laminated and nonlaminated intervals during the last 20 k.y. from Guaymas Basin, Gulf of California. The sequence is especially important because associations between laminated sediment intervals and climate change suggests historical relationships between changing oxygenation of Gulf of California bottom waters and Quaternary climate change.

\section{CHRONOLOGY}

An age model for the upper $\sim 32 \mathrm{~m}$ of Hole $893 \mathrm{~A}$ has been developed using 27 accelerator mass spectrometry radiocarbon ages of mixed planktonic foraminiferal samples from 15 stratigraphic levels (Fig. 3; Table 1). The samples were analyzed at the Center for Accelerator Mass Spectrometry (CAMS), at the Lawrence Livermore National Laboratory. Two of these samples represent duplicate analyses from the same sample. Two different age calibration methods were used to convert the radiocarbon ages to calendar ages. One was the marine calibration curve based on tree-ring dendrochronology and modeling of atmospheric ${ }^{14} \mathrm{C}$ changes in the ocean (Stuiver and Brazunias, 1993), which applies to samples with radiocarbon ages between 0 and 10,500 years. The second method used to calibrate the radiocarbon ages was developed by Bard et al. (1990a, 1990b, 1993), based on ${ }^{14} \mathrm{C}$ and ${ }^{230} \mathrm{Th}$ age determinations in corals. (The ${ }^{230} \mathrm{Th}$ ages represent actual calendar ages of samples). Two different equations employed by Bard et al. (1990a, 1990b, 1993, and pers. comm., 1994) yielded essentially identical corrected ages as discussed by Ingram and Kennett (this volume). The value used for the reservoir age in Santa Barbara Basin is 825 years (see Ingram and Kennett, this volume, for discussion). Assignments of sediment thickness in the core were corrected for all gaps (voids) resulting from sediment displacement due to gas expansion (Rack and Merrill, this volume). All data have been plotted in calendar years. The samples range in age from 1690 to 21,950 years, forming a coherent set of ages spaced at intervals of less than $\sim 2000$ years. A larger data set that includes ages based on benthic foraminiferal samples and sediments older than 22 k.y. are presented and discussed in detail by Ingram and Kennett (this volume).

The chronological spacing of samples during the last $20 \mathrm{k} . \mathrm{y}$. for benthic foraminiferal oxygen isotopic data is $\sim 450$ years, for planktonic foraminiferal isotopic data $\sim 330$ years and for planktonic foraminiferal assemblage data $\sim 500$ years. Each sample analyzed represents an interval spanning $\sim 20$ to 30 years.

\section{MATERIALS AND METHODS}

A total of 70 samples of $10 \mathrm{~cm}^{3}$ were taken for stable isotopic and foraminiferal investigations from the upper $32 \mathrm{~m}$ of Hole $893 \mathrm{~A}$, which represents the last $20 \mathrm{k.y}$. of sedimentation. The samples were taken at $\sim 50 \mathrm{~cm}$ intervals in the upper $25 \mathrm{~m}$ representing the last 16.6 $\mathrm{k} . \mathrm{y}$. and at $\sim 100 \mathrm{~cm}$ for the remaining interval down to $\sim 32 \mathrm{~m}$. These samples were processed for oxygen and carbon isotopic analyses of benthic and planktonic foraminifers and for census investigations of planktonic foraminiferal assemblages. The raw samples were oven dried at $50^{\circ} \mathrm{C}$, disaggregated using warm water, washed over a $63-\mu \mathrm{m}$ sieve, and oven dried at $50^{\circ} \mathrm{C}$. For quantitative planktonic foraminiferal studies, over 300 specimens (minimum of $\sim 250$ ) were counted in each sample ( $>150-\mu \mathrm{m}$ fraction) and relative percentages were calculated.

The methods used to obtain oxygen and carbon isotopic values for benthic foraminifers have already been described in detail by Kennett (this volume). For isotopic analysis of planktonic foraminifers, 20 to 30 specimens per sample were picked for each of two species: Neogloboquadrina pachyderma (sinistral and dextral coiling) and Globigerina bulloides. The specimens for isotopic analysis were cleaned ultrasonically in reagent-grade methanol, dried, and roasted under vacuum at $375^{\circ} \mathrm{C}$ for one hour to remove organic contaminants. The samples were treated with orthophosphoric acid at $90^{\circ} \mathrm{C}$, using an online automated carbonate $\mathrm{CO}_{2}$ preparation device. The evolved $\mathrm{CO}_{2}$ was analyzed with a Finnegan/MAT 251 light stable isotope mass spectrometer. Instrumental precision is $0.09 \%$ or better for both $\delta^{18} \mathrm{O}$ and $\delta^{13} \mathrm{C}$. All isotopic data are expressed using standard $\delta$ notation in per mil relative to Pee Dee Belemnite (PDB) carbonate standard. Isotopic analyses were related to PDB through repeated analyses of NBS-20 with values following Craig (1957) of: $\delta^{18} \mathrm{O}=-4.14 \%$ and $\delta^{13} \mathrm{C}=-1.06 \%$.

\section{RESULTS Paleoclimatic Patterns}

Quantitative planktonic foraminiferal data for Hole 893A, including that representing the last $20 \mathrm{k} . \mathrm{y}$., are provided in Kennett and Venz (this volume). Benthic oxygen isotopic data are provided in Kennett (this volume). Oxygen isotopic data from planktonic foraminifers for the last $20 \mathrm{k} . \mathrm{y}$. are presented in Table 2. Carbon isotopic data from benthic foraminifers are not discussed in this contribution because they appear to be solely a record of microenvironmental differences in the surface sediments in which the benthic foraminifers lived. Patterns of oxygen isotopic change during the last $20 \mathrm{k} . \mathrm{y}$. in benthic and planktonic foraminiferal distributions are plotted against depth and age in Figures 4-6. Quantitative changes in planktonic foraminifers are plotted against depth and age in Figures 7-10. These records are compared with an ultra-high-resolution record of inferred bottom water oxygenation from Behl (this volume). The sediments in Hole $893 \mathrm{~A}$ were classified by Behl (this volume) into a number of categories that grade at one extreme from well-laminated intervals, to indistinctly laminated, to trace laminations, to completely massive at the other extreme (Figs. 4, 5, 7, and 9). These changes were, in turn, correlated to changes in degree of oxygenation and sediment facies of Santa Barbara Basin. In each case, the patterns of change clearly reflect details of the transition between the last glacial maximum and Holocene warmth. These changes are described within our chronological framework below. Although the trends exhibited by the different paleoclimatic proxies are very similar, small differences exist in the timing of some of the changes.

Glacial Maximum: The glacial maximum, based on relatively high $\delta^{18} \mathrm{O}$ values, occurs between 20 and $16.8 \mathrm{ka}$, with the highest 
Table 2. Oxygen isotopic data for planktonic foraminifer samples, Neogloboquadrina pachyderma and Globigerina bulloides, from the upper $\sim 32 \mathrm{~m}$ ( $20 \mathrm{k} . \mathrm{y}$.) of Hole 893A, Santa Barbara Basin.

\begin{tabular}{|c|c|c|c|c|c|}
\hline $\begin{array}{l}\text { Core, section, } \\
\text { interval }(\mathrm{cm})\end{array}$ & $\begin{array}{l}\text { Depth } \\
\text { (mbsf) }\end{array}$ & $\begin{array}{l}\text { Corrected } \\
\text { depth } \\
\text { (mbsf) }\end{array}$ & $\begin{array}{l}\text { Age } \\
\text { (ka) }\end{array}$ & N. pachyderma & G. bulloides \\
\hline \multicolumn{6}{|l|}{ 146-893A- } \\
\hline $1 \mathrm{H}-1,11-13$ & 0.11 & 0.11 & 0.051 & 0.642 & -0.136 \\
\hline IH-1, 55-57 & 0.55 & 0.55 & 0.280 & 0.288 & -0.279 \\
\hline $1 \mathrm{H}-1,105-107$ & 1.05 & 1.05 & 0.556 & -0.071 & -0.279 \\
\hline IH-2, 5-7 & 1.55 & 1.53 & 0.828 & 0.210 & \\
\hline IH-2, 55-57 & 2.05 & 2.03 & 1.117 & 0.279 & -0.071 \\
\hline $1 \mathrm{H}-2,105-107$ & 2.55 & 2.53 & 1.410 & 0.445 & -0.144 \\
\hline IH-3, 5-7 & 3.07 & 3.04 & 1.713 & -0.063 & -0.148 \\
\hline IH-3, 55-57 & 3.57 & 3.54 & 2.012 & 0.470 & -0.282 \\
\hline $1 \mathrm{H}-4,5-7$ & 4.57 & 4.55 & 2.625 & 0.075 & -0.412 \\
\hline $1 \mathrm{H}-4,55-57$ & 5.07 & 5.05 & 2.932 & 0.012 & 0.076 \\
\hline $1 \mathrm{H}-4,105-107$ & 5.57 & 5.55 & 3.240 & -0.015 & \\
\hline $2 \mathrm{H}-1,55-57$ & 7.05 & 7.04 & 4.168 & -0.038 & -0.242 \\
\hline $2 \mathrm{H}-1,105-107$ & 7.55 & 7.54 & 4.482 & 0.286 & -0.273 \\
\hline $2 \mathrm{H}-2,5-7$ & 8.09 & 8.05 & 4.803 & 0.578 & -0.209 \\
\hline $2 \mathrm{H}-2,55-57$ & 8.59 & 8.55 & 5.120 & 0.501 & -0.141 \\
\hline $2 \mathrm{H}-2,105-107$ & 9.09 & 9.01 & 5.412 & -0.065 & -0.228 \\
\hline $2 \mathrm{H}-3,5-7$ & 9.59 & 9.49 & 5.718 & 0.110 & -0.169 \\
\hline $2 \mathrm{H}-3,55-57$ & 10.09 & 9.97 & 6.025 & -0.002 & -0.218 \\
\hline $2 \mathrm{H}-3,105-107$ & 10.59 & 10.47 & 6.345 & -0.005 & -0.332 \\
\hline $2 \mathrm{H}-4,5-7$ & 11.10 & 10.91 & 6.628 & 0.141 & -0.253 \\
\hline $2 \mathrm{H}-4,55-57$ & 11.60 & 11.35 & 6.911 & 0.205 & -0.434 \\
\hline $2 \mathrm{H}-4,105-107$ & 12.10 & 11.77 & 7.183 & 0.154 & 0.254 \\
\hline $2 \mathrm{H}-5,5-7$ & 12.60 & 12.27 & 7.506 & 0.444 & 0.257 \\
\hline $2 \mathrm{H}-5,55-57$ & 13.10 & 12.70 & 7.785 & 0.518 & 0.148 \\
\hline $2 \mathrm{H}-6,5-7$ & 14.10 & 13.53 & 8.325 & 0.352 & -0.362 \\
\hline $2 \mathrm{H}-6,55-57$ & 14.60 & 13.98 & 8.618 & 0.325 & -0.192 \\
\hline $2 \mathrm{H}-6,105-107$ & 15.10 & 14.47 & 8.939 & 0.716 & 0.239 \\
\hline $2 \mathrm{H}-7,5-7$ & 15.60 & 14.97 & 9.266 & -0.173 & 0.117 \\
\hline $3 \mathrm{H}-1,6-8$ & 16.06 & 16.06 & 9.982 & 1.026 & -0.080 \\
\hline $3 \mathrm{H}-1,55-57$ & 16.55 & 16.52 & 10.285 & 0.141 & -0.306 \\
\hline $3 \mathrm{H}-1,104-106$ & 17.04 & 17.01 & 10.609 & 0.923 & 0.330 \\
\hline $3 \mathrm{H}-2,4-6$ & 17.54 & 17.51 & 10.939 & 0.701 & 0.279 \\
\hline $3 \mathrm{H}-2,55-57$ & 18.05 & 18.02 & 11.277 & 1.550 & \\
\hline $3 \mathrm{H}-2,105-107$ & 18.55 & 18.52 & 11.609 & 1.373 & \\
\hline $3 \mathrm{H}-3,5-7$ & 19.05 & 19.01 & 11.934 & 1.139 & \\
\hline $3 \mathrm{H}-3,31-33$ & 19.31 & 19.26 & 12.117 & 1.788 & \\
\hline $3 \mathrm{H}-3,55-57$ & 19.55 & 19.51 & 12.267 & 1.718 & \\
\hline $3 \mathrm{H}-3,101-103$ & 20.01 & 19.93 & 12.547 & 1.791 & 0.925 \\
\hline $3 \mathrm{H}-4,5-7$ & 20.55 & 20.96 & 12.900 & 1.474 & 0.645 \\
\hline $3 \mathrm{H}-4,56-58$ & 21.06 & 20.97 & 13.241 & 1.112 & \\
\hline $3 \mathrm{H}-5,5-7$ & 22.05 & 21.90 & 13.864 & 1.373 & 0.752 \\
\hline $3 \mathrm{H}-5,28-30$ & 22.28 & 22.13 & 14.014 & 1.313 & 0.557 \\
\hline $3 \mathrm{H}-5,53-55$ & 22.53 & 22.36 & 14.164 & 1.529 & 0.625 \\
\hline $3 \mathrm{H}-5,86-88$ & 22.86 & 22.58 & 14.320 & 1.531 & 0.713 \\
\hline $3 \mathrm{H}-6,5-7$ & 23.77 & 23.43 & 14.778 & 1.330 & 0.554 \\
\hline $3 \mathrm{H}-6,7-9$ & 23.57 & 23.29 & 14.791 & 1.203 & 0.649 \\
\hline $3 \mathrm{H}-6,55-57$ & 24.05 & 23.71 & 15.081 & 1.197 & 0.568 \\
\hline $3 \mathrm{H}-6,84-86$ & 24.34 & 24.00 & 15.280 & 1.159 & 0.745 \\
\hline $3 \mathrm{H}-7,5-7$ & 25.05 & 24.70 & 15.748 & 1.841 & \\
\hline $3 \mathrm{H}-7,52-54$ & 25.52 & 25.18 & 16.070 & 2.210 & \\
\hline $3 \mathrm{H}-\mathrm{C}, 20-22$ & 26.01 & 25.66 & 16.400 & 1.923 & 0.430 \\
\hline $4 \mathrm{H}-1,5-7$ & 25.55 & 25.55 & 16.323 & 2.641 & \\
\hline $4 \mathrm{H}-1,32-34$ & 25.82 & 25.82 & 16.506 & 2.241 & 2.675 \\
\hline $4 \mathrm{H}-1,86-88$ & 26.36 & 26.13 & 16.738 & 2.552 & 3.019 \\
\hline $4 \mathrm{H}-1,105-107$ & 26.55 & 26.32 & 16.844 & 2.825 & \\
\hline $4 \mathrm{H}-2,55-57$ & 27.55 & 27.25 & 17.475 & 2.638 & 2.771 \\
\hline $4 \mathrm{H}-3,7-9$ & 28.57 & 28.23 & 18.142 & 2.684 & 2.704 \\
\hline $4 \mathrm{H}-3,106-108$ & 29.56 & 29.16 & 18.775 & 2.248 & 2.567 \\
\hline $4 \mathrm{H}-4,57-59$ & 30.57 & 30.12 & 19.431 & 2.380 & 2.412 \\
\hline $4 \mathrm{H}-5,9-11$ & 31.59 & 30.91 & 19.971 & 2.546 & \\
\hline
\end{tabular}

$\delta^{18} \mathrm{O}$ values between 18.5 and $16.8 \mathrm{ka}$ (Figs. 5 and 6). Cool planktonic foraminiferal assemblages, reflected by changes in relative dominance of dextral and sinistral $N$. pachyderma and by coiling ratio changes of this species, indicate the age of the glacial maximum to be older than 16.5 ka (Fig. 9).

Termination IA: The earliest post-glacial warming trend usually referred to as Termination IA occurred between $\sim 16.5$ and $15 \mathrm{ka}$. This warming trend is reflected in Hole $893 \mathrm{~A}$ by a $1 \%$ decrease of benthic foraminiferal $\delta^{18} \mathrm{O}$, a $1.75 \%$ decrease in $\delta^{18} \mathrm{O}$ of $N$. pachyder$m a$, and a $2.6 \%$ decrease in $\delta^{18} \mathrm{O}$ of $G$. bulloides (Fig. 5). Major changes occurred in planktonic foraminiferal assemblages as reflected by a change in dominance from sinistral ( $60 \%)$ to dextral $(\sim 20 \%$ to $70 \%$ ) forms of $N$. pachyderma, and in the switch from dominantly sinistral ( $90 \%$ ) to dextral ( $>98 \%$ ) coiling of this species (Fig. 9). Inferred warming of surface waters is very rapid (between $\sim 16.5$ and 16 ka) during Termination IA as indicated by changes in the planktonic foraminiferal assemblages and the $\delta^{18} \mathrm{O}$ decrease in $G$. bulloides. This warming is shown to be less rapid by the $\delta^{18} \mathrm{O}$ decrease in $N$. pachyderma and rather gradual decease in $\delta^{18} \mathrm{O}$ of benthic foraminifers. Slight diachronism occurred in the warming trend exhibited by the various parameters marking Termination IA. The mid-point of the warming marking Termination IA, as expressed by the planktonic foraminiferal assemblage changes (16.5 ka; Fig. 9) and the $\delta^{18} \mathrm{O}$ decrease in G. bulloides (16.4 ka; Fig. 6), is earlier than the mid-point of warming shown by the $\delta^{18} \mathrm{O}$ decreases in $N$. pachyderma $(15.7 \mathrm{ka})$ and in benthic foraminifers (15.5 ka; Fig. 5).

Bølling/Allerød: Between the warming that marks Termination IA and the Younger Dryas cool interval that follows is an interval of relatively little change in most paleoclimatic parameters (Figs. 5, 6, and 9). This represents a pause in the warming trend during deglaciation as recorded in Hole 893A. The age of the beginning of this interval differs depending on the parameter measured. A stabilization of planktonic foraminiferal assemblage changes (except for the relative abundance of dextral $N$. pachyderma, which exhibits high variability during this interval) begins at $16.3 \mathrm{ka}$ (Fig. 9). This compares with stabilization of the negative $\delta^{18} \mathrm{O}$ trend in $G$. bulloides at 16.5, in $N$. pachyderma at $15.2 \mathrm{ka}$, and in benthic foraminifers at $15.0 \mathrm{ka}$ (Figs. 5 and 6). Likewise, the end of this interval of relative climatic stability ranges between 13.3 and $12.9 \mathrm{ka}$. The maximum duration of the interval is therefore $3.6 \mathrm{k} . \mathrm{y}$., extending between 16.5 and $12.9 \mathrm{ka}$. This interval correlates temporally with the Bølling/Allerød Interstadial. Short-term climate instability during the Bølling/Allerød reported in sediment cores from the Norwegian Sea (Karpuz and Jansen, 1992) was not observed in our study.

Younger Dryas Cool Episode: Following the Bølling/Allerød Interstadial, a distinct cooling trend is recorded by a $0.5 \%$ increase in $\delta^{18} \mathrm{O}$ in benthic foraminifers and a $0.8 \%$ increase in $\delta^{18} \mathrm{O}$ in $N$. pachyderma (Figs. 5 and 6). Cooler planktonic foraminiferal assemblages during this interval are marked by an $12 \%$ decrease in dextral-coiled $N$. pachyderma, a $10 \%$ increase in sinistral-coiled $N$. pachyderma, and a reduction in dextral coiling in N. pachyderma from $100 \%$ to $80 \%$ (Fig. 9). The beginning of the cooling trend in Hole 893A occurs at $\sim 13 \mathrm{ka}$ (range between 12.9 and $13.2 \mathrm{ka}$ ), while the end occurs at $\sim 11.2 \mathrm{ka}$. This interval correlates with the Younger Dryas cool episode of northern Europe and in marine sequences elsewhere.

A high-resolution chronology for the Younger Dryas cooling event in Hole 893A, established with radiocarbon dating of six planktonic foraminiferal samples, indicates an age from between 11,980 to $10,630{ }^{14} \mathrm{C}$ years. To compare these radiocarbon ages with other radiocarbon ages determined for the Younger Dryas, the reservoir age of 825 years must be subtracted from the radiocarbon age. The "reservoir-corrected ${ }^{14} \mathrm{C}$ age" for the beginning and end of the Younger Dryas in the Santa Barbara Basin is thus 11,155 to 9,805 years BP. The "reservoir-corrected" ${ }^{14} \mathrm{C}$ age for the beginning of the Younger Dryas in Santa Barbara Basin $(11,155 \mathrm{yr})$ is similar to that obtained by Denton and Hendy (1994) for wood samples in glacial deposits from New Zealand, which is $11,050{ }^{14} \mathrm{C}$ years BP. It also similar to the reservoir-corrected ${ }^{14} \mathrm{C}$ dates from the North Atlantic Ocean $\left(11,200\right.$ to $11,010{ }^{14} \mathrm{C}$ yr BP) from cores SU81-18 (Duplessy, 1989) and Troll 3.1 (Lehman and Keigwin, 1992).

Corrected age (or calendar-year age) for the beginning of the Younger Dryas cooling event in Santa Barbara Basin is 12,971 ka. The corrected age for the end of the Younger Dryas in Santa Barbara Basin is poorly constrained, because it occurs during a 1300-yr radiocarbon plateau, and falls between 10,900 and 12,300 yr BP (Ingram and Kennett, this volume). This plateau has been defined by Bard et al. (1993), Edwards et al. (1993), and Gray et al. (1993). We have used an interpolated age of $11,200 \mathrm{yr}$ BP for the end of the Younger Dryas.

The ages for the Younger Dryas in Santa Barbara Basin agree well with those based on counting annual layers in Greenland ice cores, which indicate the Younger Dryas occurred between $12,940 \pm 260 \mathrm{yr}$ 

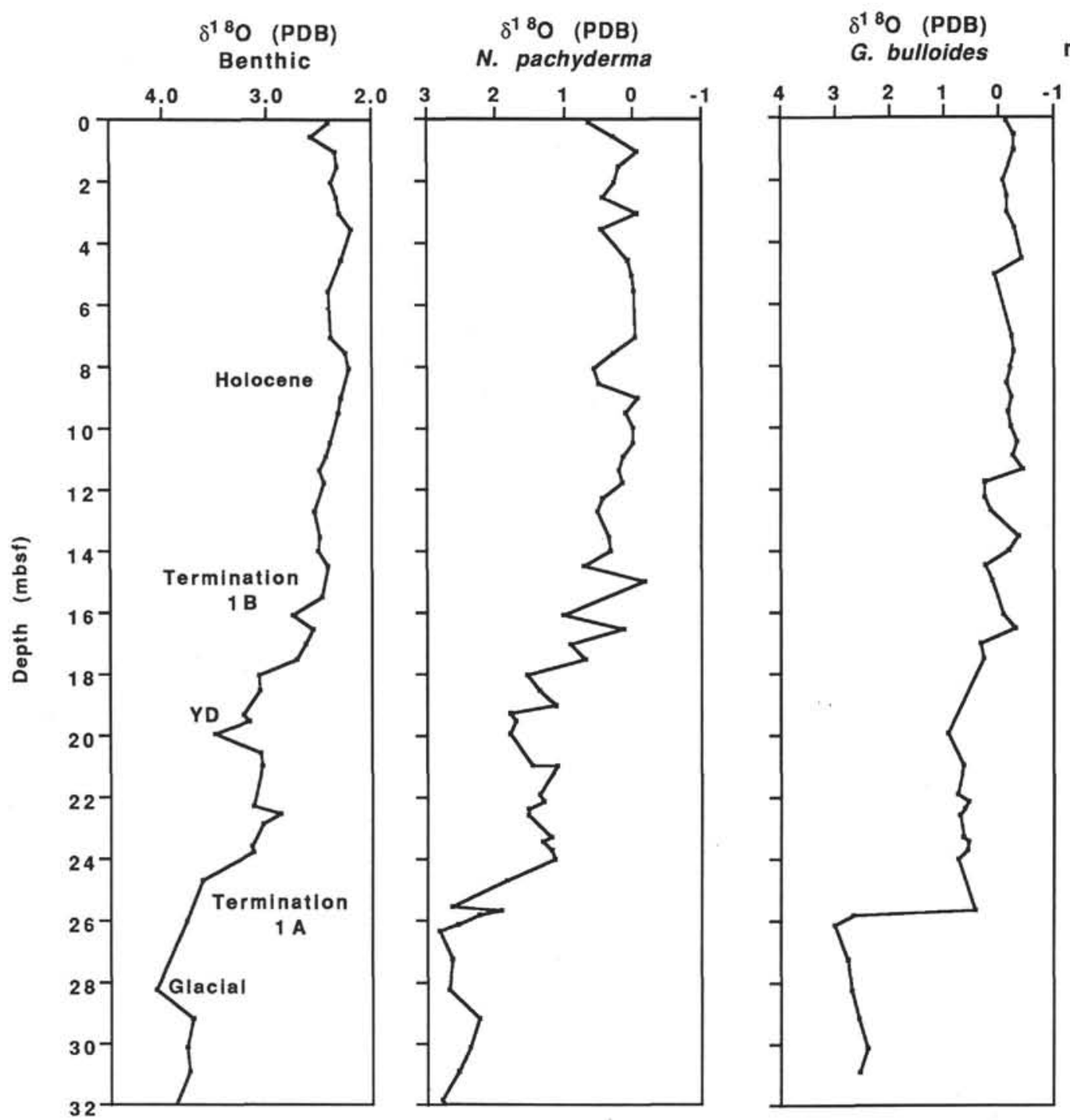

Sediment structure massive $\longleftrightarrow$ well-laminated

Figure 4. Oxygen isotopic records of benthic foraminifers and the planktonic foraminifers Neogloboquadrina pachyderma and Globigerina bulloides compared with changes in sediment structure in the upper $32 \mathrm{mbsf}$ in Hole 893A, Santa Barbara Basin. Sediment structures grade from well laminated to massive with categories as follows: (1) well laminated; (2) indistinctly laminated; (3) trace laminations; and (4) massive or nonlaminated (from Behl, this volume). Lamination data was smoothed using a 99-cm running average. These changes have been correlated to changes in the degree of oxygenation of Santa Barbara Basin by Behl (this volume). $\mathrm{YD}=$ Younger Dryas; $\mathrm{B} / \mathrm{A}=\mathrm{B} \emptyset$ lling/Allerød.

BP and 11,640 \pm 250 yr BP (Alley et al., 1993a; Alley et al., 1993b; Johnson et al., 1992). The duration of the Younger Dryas in Santa Barbara Basin is between 670 and $2070 \mathrm{yr}$ (we show 1,730 yr), not inconsistent with the 1300 -yr duration counted in ice core layers. Based on ${ }^{14} \mathrm{C}$ dating of marine and lacustrine sediments in the North Atlantic region, the Younger Dryas cooling event began between 11,200 and 11,000 years BP and ended between 10,200 and 10,000 ${ }^{14} \mathrm{C}$ years BP (Karpuz and Jansen, 1992; Edwards et al., 1993). In calendar years, this translates into a maximum range of 13.1 to $11.3 \mathrm{ka}$, similar to the age of the Younger Dryas in Santa Barbara Basin.

In the early Holocene following $11 \mathrm{ka}$, further warming is shown by decreased oxygen isotopic values (beginning at $\sim 11.2 \mathrm{ka}$, following the end of the Younger Dryas cooling; Figs. 5 and 6). At this time, $\delta^{18} \mathrm{O}$ values of benthic foraminifers exhibit a rather steady decrease of about $0.9 \%$ until they reach a minimum at $\sim 5 \mathrm{ka}$. In a series of oscillations, $\delta^{18} \mathrm{O}$ values of $N$. pachyderma also decrease an additional $1.4 \%$ to values close to $0 \%$ at $\sim 6 \mathrm{ka}$ while $\delta^{18} \mathrm{O}$ values of $G$. bulloides decrease from 11 to $10 \mathrm{ka}$, after which values oscillate by $\sim 0.75 \%$ during the Holocene. These decreases in $\delta^{18} \mathrm{O}$ values mark Termination IB. Planktonic foraminiferal assemblages also reflect higher seasurface temperatures after $11 \mathrm{ka}$ with the consistent occurrence for the remainder of the Holocene of distinctly warmer species including Globigerinoides ruber, Neogloboquadrina dutertrei, Globorotalia inflata, and Orbulina universa (Fig. 10). Following the Younger Dryas, the relative warmth of planktonic foraminiferal assemblages is indicated also by a dominance of dextral $N$. pachyderma (generally $>50 \%$ ), very low frequencies of sinistral $N$. pachyderma, and high ratios of dextral to sinistral $N$. pachyderma (mainly $>90 \%$ dextral).

In the late Holocene, following $6 \mathrm{ka}$, variations in $\delta^{18} \mathrm{O}$ values of benthic foraminifers are less than $0.25 \%$, while variations in $\delta^{18} \mathrm{O}$ values of planktonic foraminifers (both N. pachyderma and G. bulloides) are less than $\sim 0.75 \%$ (Figs. 5 and 6 ). More detailed work is required on oxygen isotopic oscillations during the last 11 k.y. to determine if they reflect climatic changes of regional or global significance. Nevertheless, both the planktonic foraminiferal assemblages and oxygen isotopic data of $N$. pachyderma are internally consistent 

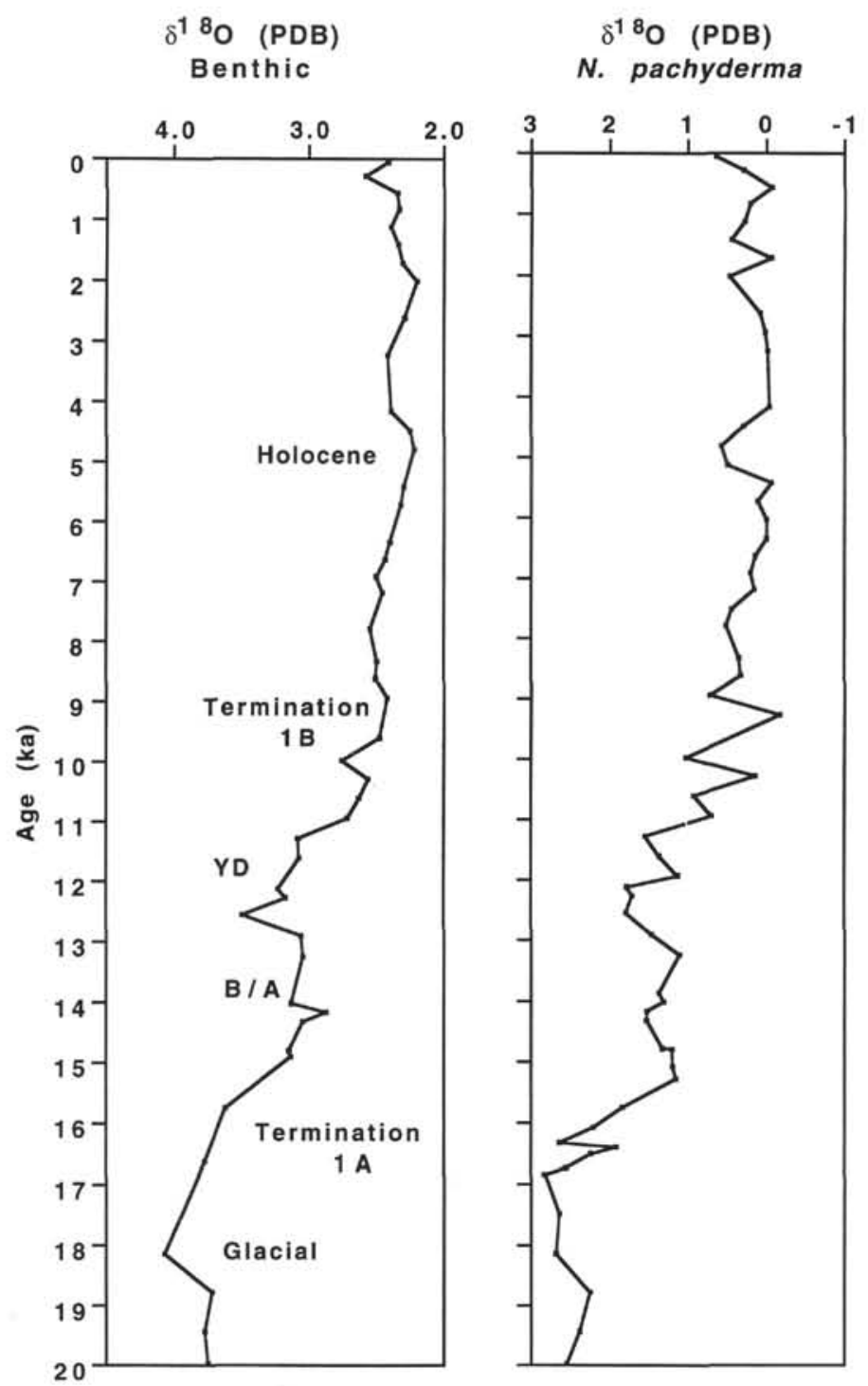

$\delta^{18} \mathrm{O} \quad(\mathrm{PDB})$

G. bulloides

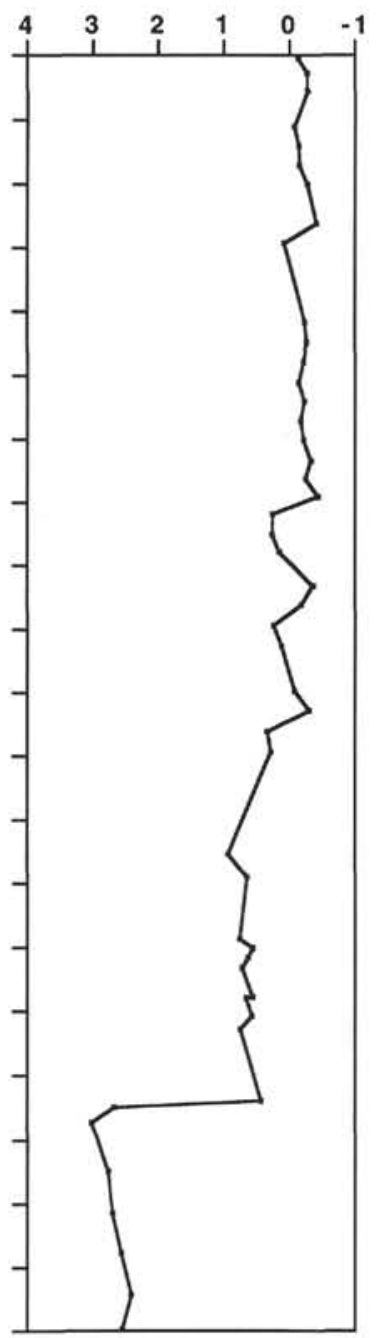

Sediment structure massive $\leftrightarrow$ well-laminated

Figure 5. Oxygen isotopic records of benthic foraminifers and the planktonic foraminifers Neogloboquadrina pachyderma and Globigerina bulloides compared with changes in sediment structure for the last $20 \mathrm{k} . \mathrm{y}$. in Hole 893A. Santa Barbara Basin. For further details see Figure 4 caption.

in indicating a distinct cooling of surface waters during an interval centered at 5 ka (Figs. 5, 6, and 9). However, there is no increase in $\delta^{18} \mathrm{O}$ values of $G$. bulloides at this time.

During much of the last 20 k.y., a distinct gradient has existed in the $\delta^{18} \mathrm{O}$ values between $N$. pachyderma, which is inferred to live in the thermocline, and $G$. bulloides, which lives near the ocean surface (Fig. 6). This gradient was small (up to $\sim 0.4 \%$ ) during the last glacial maximum. Termination IA is associated with a significant increase in this gradient (up to $\sim 1.5 \%$ ). By $15.2 \mathrm{ka}$, at the beginning of the Bølling/Allerød, the gradient decreased and varied from $0.5 \%$ to $0.8 \%$ until the Younger Dryas. G. bulloides is relatively rare to absent during much of the Younger Dryas interval. After $11 \mathrm{ka}$, several episodes showing a distinct gradient $(0.3 \% 0-0.8 \%$ ) between these two species are separated at 2000 year intervals with events marked by little to no gradient. These occurred at $9.3 \mathrm{ka}, 7.3 \mathrm{ka}, 5.3 \mathrm{ka}$, and $3.2 \mathrm{ka}$ (Fig. 6). The most recent interval is not periodic having occurred at $\sim 1.7 \mathrm{ka}$.

\section{STRATIGRAPHIC RELATIONS BETWEEN SEDIMENT LAMINATIONS AND CLIMATE CHANGE}

The sediments of Hole 893A exhibit considerable variation between well-laminated to completely massive (nonlaminated). The general pattern of change in lamination strength for the last $20 \mathrm{k} . \mathrm{y}$. is shown in Figures 4, 5, 7, and 9. The sequence is divided into four zones marked by a dominant sediment facies: massive sediments from 20.0 to $15.2 \mathrm{ka}$; laminated sediments from 15.2 to $12.9 \mathrm{ka}$; massive sediments from 12.9 to $11.0 \mathrm{ka}$; and laminated sediments from $11.0 \mathrm{ka}$ to the present day. The laminated zones include sediments that exhibit strong to trace laminations or even thin intervals with no laminations. The massive zones contain minor intervals with very weak trace laminations.

A strong correlation exists between the stratigraphic distribution of massive and laminated intervals and climatic history during the 
last 20 k.y. in Hole 893A (Fig. 5 and 6). Sediments deposited during the last glacial maximum and Termination $1 \mathrm{~A}$ are massive, followed upwards by laminated sediments of the Bølling/Allerød Interstadial, in turn followed upward by massive sediments deposited during the Younger Dryas cool interval, and thence upward into laminated sediments associated with Holocene warmth.

The upward change from massive to laminated sediments at 15.2 ka coincides precisely with the end of the negative shift in $\delta^{18} \mathrm{O}$ values of $N$. pachyderma where values are $\sim-1 \%$ and close to the end of the negative shift in $\delta^{18} \mathrm{O}$ values of benthic foraminifers at $15 \mathrm{ka}$ (Fig. 5 ). This sedimentary facies boundary thus coincides closely with the end of Termination IA and the beginning of the Bølling-Allerød as represented by changes in these parameters. The change from massive to laminated sediments is $\sim 1.1 \mathrm{k} . \mathrm{y}$. younger than the end of Termination IA warming (marked by changes in planktonic foraminiferal assemblages and by decreased $\delta^{18} \mathrm{O}$ values of $G$. bulloides).

Close correspondence also occurs between the boundary that marks the change from laminated to massive sediments at $12.9 \mathrm{ka}$ and the beginning of cooling at $13.0 \mathrm{ka}$ (range 13.2 to $12.9 \mathrm{ka}$ ) as represented by oxygen isotopic changes in planktonic and benthic foraminifera, and assemblage changes in planktonic foraminifers (Figs. 5 and 9). This is considered to represent the beginning of the Younger Dryas cool episode. Likewise, the boundary at $11.0 \mathrm{ka}$ that marks the upward change from massive to laminated sediments closely corresponds with the end of cooling at $11.2 \mathrm{ka}$ exhibited by the isotopic and faunal changes marking the end of the Younger Dryas (Figs. 5 and 9). The beginning and end of the cooling trend that represents the Younger Dryas coincides with $\delta^{18} \mathrm{O}$ values of $N$. pachyderma of about $-1.0 \%$.

The Holocene sequence younger than $11.0 \mathrm{ka}$ at Hole $893 \mathrm{~A}$ is overwhelmingly dominated by laminated sediments, containing no extensive massive intervals. Oxygen isotopic values of foraminifers associated with the sediments of Holocene age are lower than those of the cooler intervals during the Younger Dryas, Termination IA, and the last glacial maximum. Planktonic foraminiferal assemblages at all levels exhibit characteristics indicative of greater warmth than the assemblages associated with the Younger Dryas. Furthermore, although frequencies of sinistral and dextral $N$. pachyderma in Holocene assemblages younger than $11 \mathrm{ka}$ and those of the Bølling/ Allerød Interstadial are similar, the appearance in persistent abundance at $11.0 \mathrm{ka}$ of additional warm water taxa (Fig. 10) heralds a further increase in surface water temperatures relative to the Bølling/ Allerød and is therefore consistent with the oxygen isotopic data.

\section{DISCUSSION \\ Climate Change}

Climatic evolution during the last $20 \mathrm{ka}$ in Hole $893 \mathrm{~A}$ is described at high-resolution and within a detailed Accelerator Mass Spectrometry (AMS) ${ }^{14} \mathrm{C}$ age framework, by oxygen isotopic changes in benthic and planktonic foraminifers (Figs. 5 and 6). The last glacial maximum (centered at $18 \mathrm{ka}$ in Hole $893 \mathrm{~A}$ ) is followed by deglaciation beginning at $\sim 16.5 \mathrm{ka}$. Deglaciation proceeded in two steps correlated with Termination IA and IB. The terminations are separated by a warming pause between $\sim 15.5$ and $13.3 \mathrm{ka}$, correlative with the Bølling/Allerød Interstadial, and a subsequent cool interval between 13.0 and 11.2, ka correlative with the Younger Dryas. Termination IB represents further warming between $\sim 11$ and $9 \mathrm{ka}$. This sequence of climatic changes is also recorded by assemblage changes in planktonic foraminifers (Fig. 9 and 10). The magnitude of surface water temperature changes in Hole $893 \mathrm{~A}$ during the last $20 \mathrm{k} . \mathrm{y}$. has been estimated by Kennett and Venz (this volume) by comparison with modern distribution patterns in planktonic foraminifers in the northeast Pacific. The Subarctic Assemblage, dominated by sinistral $N$. pachyderma, is associated with the last glacial maximum. This assemblage is replaced during Termination IA by the Transitional As-

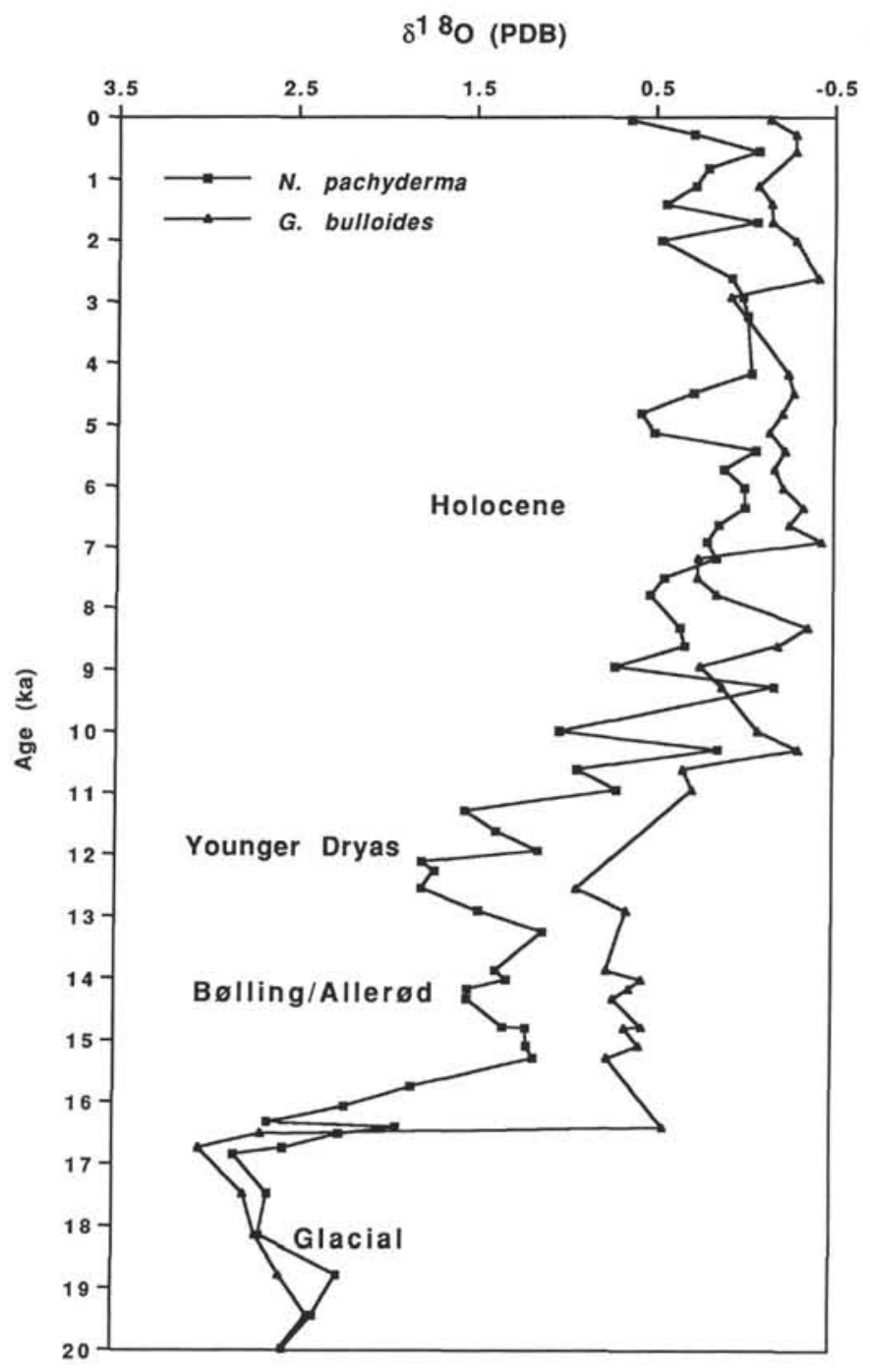

Figure 6. Oxygen isotopic records of the planktonic foraminifers Neogloboquadrina pachyderma and Globigerina bulloides for the last 20 k.y. in Hole 893A. Climatic events are indicated.

semblage marked by higher diversity and dominated by dextral $N$. pachyderma characteristic of the Holocene. Average sea-surface temperatures in Santa Barbara Basin are considered to have increased from $\sim 7^{\circ}-8^{\circ} \mathrm{C}$ during the glacial maximum to $\sim 15^{\circ} \mathrm{C}$ during the Holocene warmth, or a total average increase of $7^{\circ}-8^{\circ} \mathrm{C}$ (Kennett and Venz, this volume). Deglacial warming in Santa Barbara Basin was significantly greater than values determined for the California Current further to the north $\left(41^{\circ}\right.$ to $43^{\circ} \mathrm{N}$; Moore, 1973). Warming of surface waters of Santa Barbara Basin during deglaciation was associated with an increase in the temperature gradient between the ocean surface and the thermocline was inferred from increased oxygen isotopic differences between $N$. pachyderma and $G$. bulloides (Fig. 6). This gradient was highest during the early stages of deglaciation until $\sim 11$ ka after which it exhibits considerable variation.

Estimates have been made about the magnitude of the cooling during the Younger Dryas. In the northernmost Atlantic region and northwest Europe, Younger Dryas cooling represents a return of climate to a near-glacial state (Broecker and Denton, 1989, and references therein). In Hole 893A, Younger Dryas cooling does not reflect a return to a full glacial state. In Santa Barbara Basin, the cooling of surface waters during the Younger Dryas was limited to a few degrees. Oxygen isotopic values of planktonic foraminifers increased at this time by $0.8 \% \circ$ (Figs. 5 and 6 ), representing a decrease of surface 

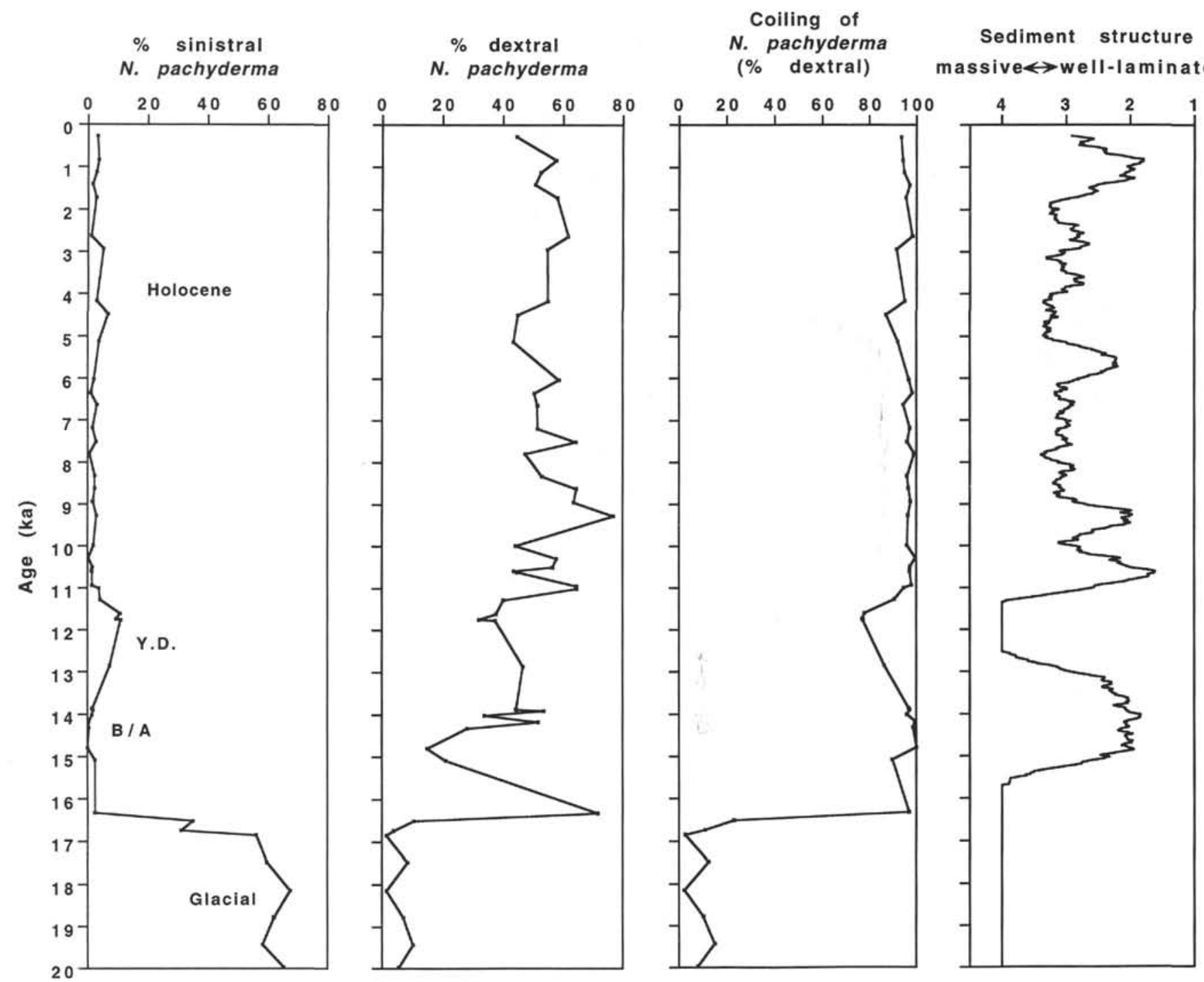

Figure 7. Changes in Neogloboquadrina pachyderma characteristics and in sediment structures in the upper 32 mbsf in Hole $893 \mathrm{~A}$. Shown are percent frequency changes of dextral and sinistral forms of $N$. pachyderma in planktonic foraminiferal assemblages (>150 $\mu \mathrm{m})$ and of the percent dextral coiling forms within N. pachyderma. Sediment structures grade from well-laminated to massive with categories as in Figure 4 caption. Further details as in Figure 4 caption.

water temperatures of $\sim 3^{\circ} \mathrm{C}$. At this time, climate in Santa Barbara Basin returned to that recorded at the mid-point of Termination IA: equal to the mid-point of return to a full glacial episode (Fig. 5). Modest changes in the planktonic foraminiferal assemblages during the Younger Dryas also reflect limited surface water cooling. The continued presence of the Transitional Assemblage during this interval indicates that average surface water temperatures in Santa Barbara Basin remained higher than $10^{\circ} \mathrm{C}$ (Kennett and Venz, this volume). Nevertheless, assemblages of intermediate composition suggest that the $10^{\circ} \mathrm{C}$ surface water isotherm must have been near the basin at this time. Although the effects of Younger Dryas cooling were much less drastic in Southern California than in the North Atlantic, they nevertheless represent a significant reversal to cooler conditions.

The distinct warming trend that immediately followed the Younger Dryas from 11 ka to $\sim 9$ ka represents Termination IB (Figs. 5 and 6). This is the second rapid warming step leading to Holocene warmth. Average sea-surface temperatures appear to have changed little in Santa Barbara Basin after 9,000 years ago (although large seasonal variations almost certainly occurred), other than during a slight but distinct cooling centered at $5.0 \mathrm{ka}$. Oxygen isotopic variations in planktonic foraminifers (G. bulloides and N. pachyderma) of no more than $0.8 \%$ (Figs. 5 and 6 ) suggest that average sea-surface temperatures varied by no more than $\sim 3^{\circ} \mathrm{C}$ during this time, an interpretation supported by associated relatively small changes in planktonic foraminiferal assemblages (Figs. 9 and 10). These changes are much smaller than earlier estimates of $12^{\circ} \mathrm{C}$ (February) during the Holocene (last $8000 \mathrm{yr}$ ) in Santa Barbara Basin based on variations in radiolarian assemblages in (Pisias, 1978, 1979). This suggested total paleotemperature amplitude is similar to the present-day seasonal sea-surface temperature range $\left(11^{\circ} \mathrm{C}\right)$ in Santa Barbara Basin. Thus the extent of suggested Holocene paleotemperature variation differs significantly between these two investigations. This earlier estimate of the range of Holocene sea-surface temperature changes is even larger than the average $7^{\circ}-8^{\circ} \mathrm{C}$ estimated difference in sea-surface temperatures we suggest occurred between full glacial maximum and Holocene warmth.

\section{Relations between Climatic and Basinal Ventilation Changes}

In this study, we show that a close association has existed between major climate change and switches between dominantly laminated 

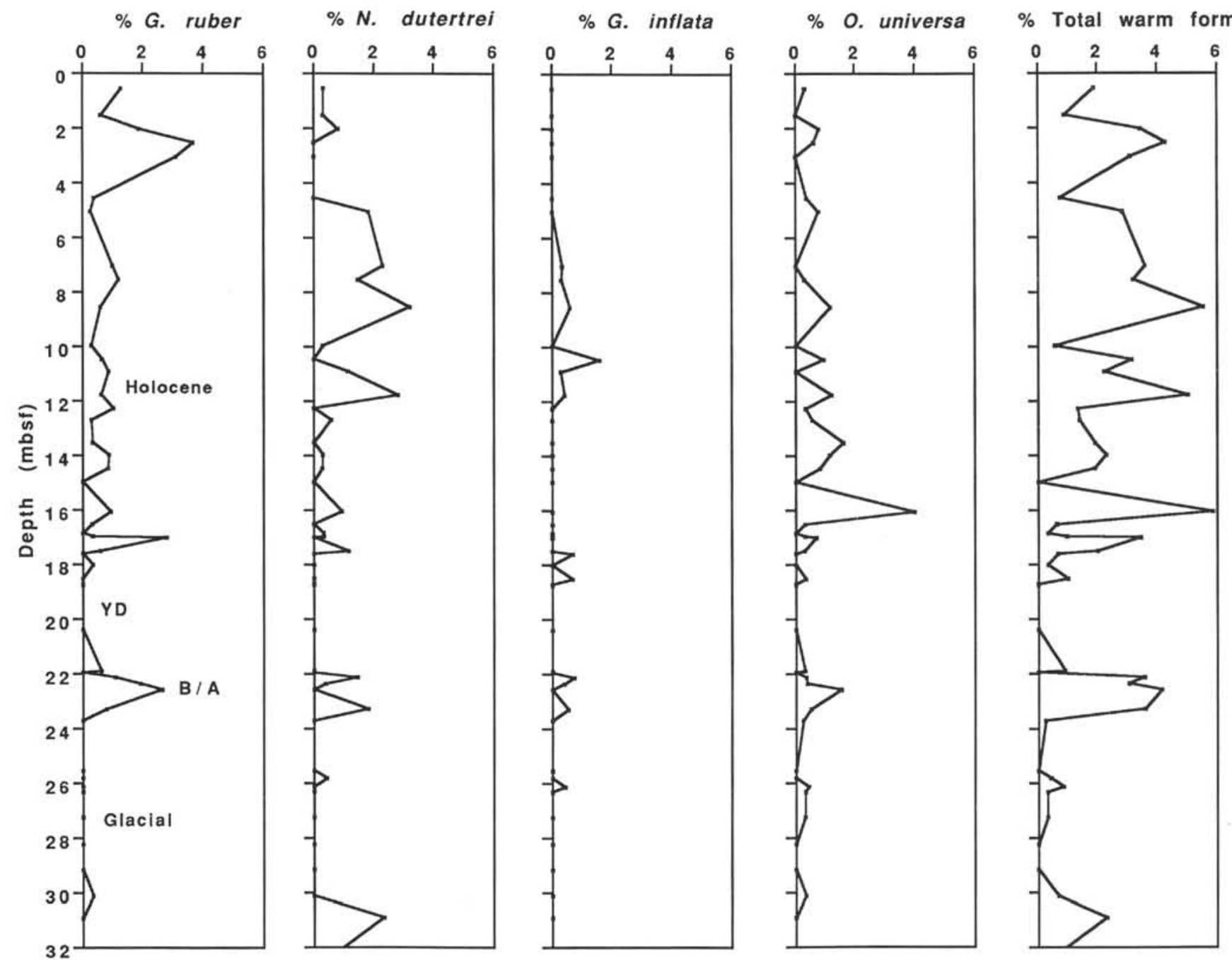

Figure 8. Percent frequency changes of Globigerinoides ruber, Neogloboquadrina dutertrei, Globorotalia inflata, and Orbulina universa and the sum of these percentages shown as total warm forms within planktonic foraminiferal assemblages in the upper $32 \mathrm{~m}$ in Hole $893 \mathrm{~A}$. YD $=$ Younger Dryas; $\mathrm{B} / \mathrm{A}=\mathrm{B} \Leftrightarrow \mathrm{lling} /$ Allerød.

and nonlaminated (massive) sediment intervals in Hole 893A (Figs. 5 and 9). It is now well established that the laminated sediment intervals in Hole 893A were deposited during times of low dissolved oxygen levels of basinal waters when active benthic assemblages were absent (Kennett, Baldauf, et al., 1994; Behl, this volume). Presentday basinal waters are suboxic $(<0.1 \mathrm{~mL} / \mathrm{L}$ oxygen $)$ below $\sim 475 \mathrm{~m}$. In contrast, massive sediments reflect times of higher oxygen concentrations when an active benthos was supported. This relationship between oxygen content and sedimentary facies is shown by presentday lateral changes in Santa Barbara Basin (Savrda et al., 1984). Therefore, the alternations between laminated and massive intervals in Hole $893 \mathrm{~A}$ reflect changes in the ventilation of the basin.

The sequence since $20 \mathrm{ka}$ at Hole $893 \mathrm{~A}$ therefore records a close association between significant climate change of global proportions and changes in the ventilation of Santa Barbara Basin. The basin was relatively well-ventilated during glacial intervals and poorly ventilated during interstadial and interglacial intervals. Thus, the interval from the last glacial maximum to the beginning of the Bølling/Allerød Interstadial and the Younger Dryas event were relatively welloxygenated. In contrast, the basin was poorly ventilated during the Bølling/Allerød Interstadial and the Holocene after $11 \mathrm{ka}$. Similar close relations between climatic history and changes from laminated to nonlaminated sediments in the latest Quaternary also occur in Deep Sea Drilling Project Site 480 in the Guaymas Basin, Gulf of California at a depth of $655 \mathrm{~m}$ (Keigwin and Jones, 1990). Nonlaminated sediments are associated with cooler climatic conditions of the last glacial and the Younger Dryas, and laminated sediments are associated with the warming associated with the Bølling/Allerød and the Holocene interval following the Younger Dryas.

Reasons for the changes in oxygen concentrations in Santa Barbara Basin during the latest Quaternary have been discussed by Kennett, Baldauf, et al. (1994). Three processes were described that may have contributed to increased oxygenation of bottom waters in the basin: (1) lowering of the impinging oxygen minimum zone below sill depth during glacioeustatic fall in sea level; (2) shifting of high surface productivity offshore of Santa Barbara Basin during lowered sea level or altered wind regimes; and (3) increased oxygen content of intermediate waters advecting upwards into Santa Barbara Basin from the west. The changing interplay of all three processes simultaneously was suggested to have caused the changes in oxygen levels in the basin. However, we suggest that these various processes were not of equal importance. For instance, it is unlikely that increased oxygenation of basin waters could directly have been the result of a fall in sea level, because the Younger Dryas cooling was associated with a 

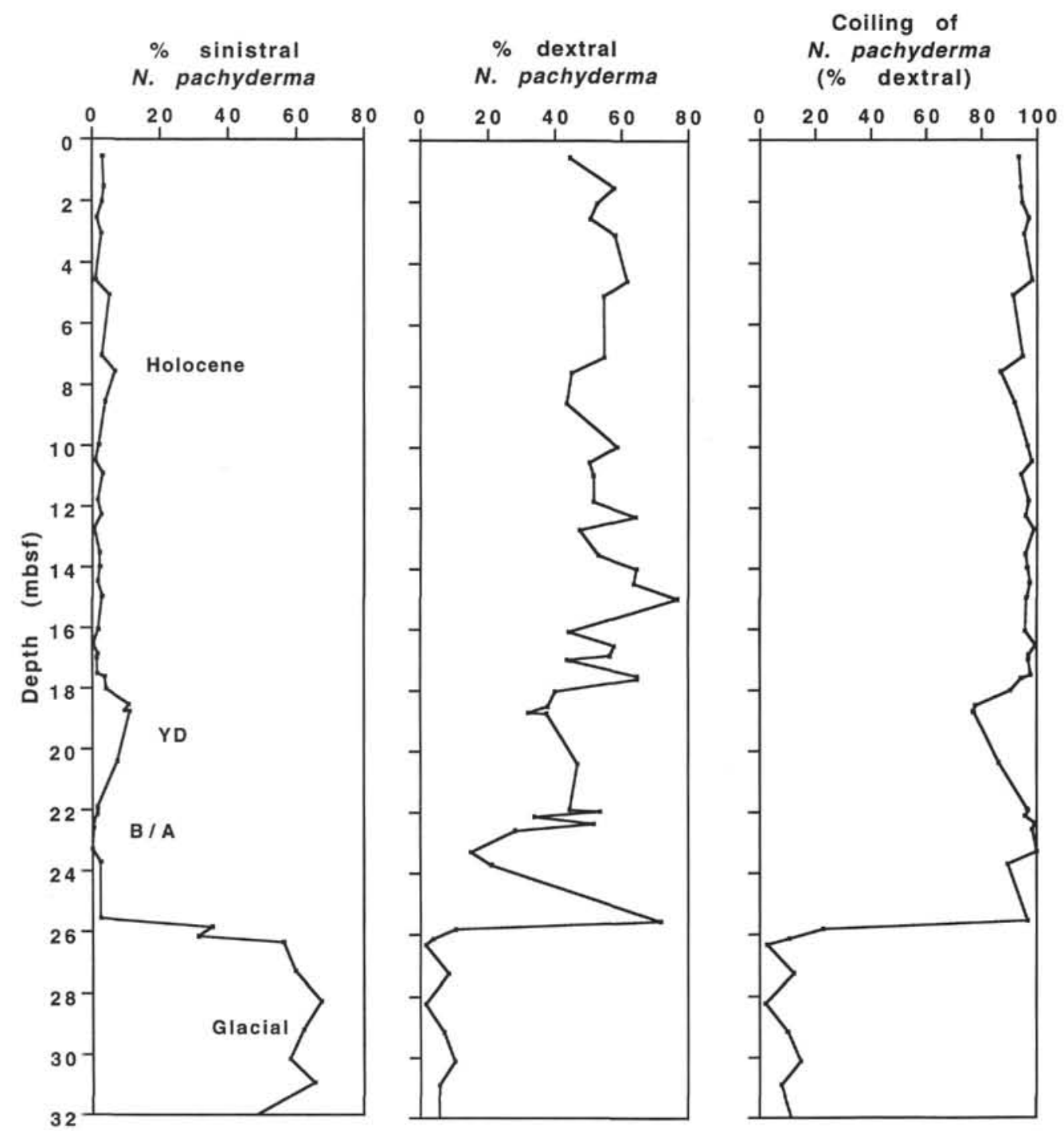

Sediment structure massive $\longleftrightarrow$ well-Iaminated

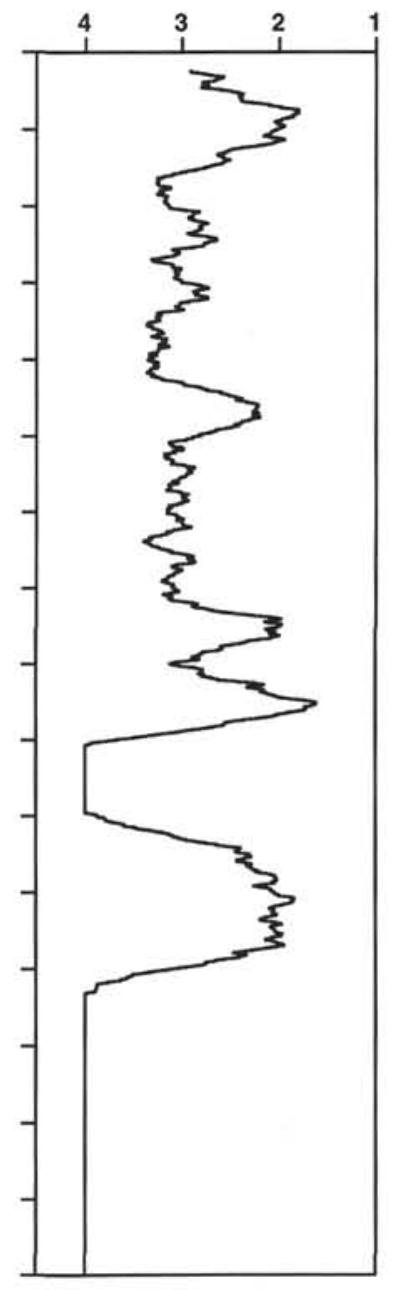

Figure 9. Changes in Neogloboquadrina pachyderma characteristics and in sediment structures during the last 20 k.y. in Hole $893 \mathrm{~A}$. Frequencies of sinistral and dextral $N$. pachyderma are percent of total assemblage: coiling ratio (\% dextral) shown for N. pachyderma assemblages. For further details see Figure 8 caption.

pause in the sea-level rise, rather than a fall during the deglacial interval (Fairbanks, 1989). Furthermore, similar relations between laminated sediment intervals and climate change are recorded in the Guaymas Basin, Gulf of California (Keigwin and Jones, 1990), which is not partially isolated (silled) and could not have been affected by changes in sea level. Also, Behl (this volume) finds greater than twelve major episodes of oxygen depletion during oxygen isotope Stage 3 which cannot be correlated with periods of high sea level.

Similarly, the stratigraphic record does not support the hypothesis that increased ventilation in the basin was caused mainly by the seaward shift in the zone of high surface water productivity. This is because the basin was no more isolated from the zone of coastal upwelling during the Younger Dryas than during the preceding Bølling/Allerød Interstadial.

We therefore suggest that the changes in oxygen concentrations in intermediate waters from the Pacific were largely responsible for controlling the late Quaternary cycles of oxygenation/dysaerobia in Santa Barbara Basin (Fig. 11), in agreement with the explanation by Keigwin and Jones (1990) for similar cycles in Guaymas Basin, Gulf of California. If this interpretation is correct, sediments in Santa Barbara Basin have recorded changes in the oxygen levels of intermedi- ate waters advecting upwards near the coast of California during the latest Quaternary.

The sharpness of the transitions between the massive and welllaminated intervals suggests that the inferred switches in circulation occurred within decades. This observation is consistent with evidence from the Greenland Ice Sheet of very rapid climatic changes at the boundary between the glacial maximum and Bølling/Allerød, and at the end of the Younger Dryas (Alley et al., 1993a; Alley et al., 1993b). Threshold levels in the climate system have been implicated to account for such rapid change.

\section{Role of Ocean Circulation Change in Ventilation History of Santa Barbara Basin}

Our work demonstrates, therefore, that Santa Barbara Basin and the Gulf of California (Keigwin and Jones, 1990) have recorded oscillations between two fundamentally different states linked with global climate change during the last 20 k.y. The basin was relatively well ventilated during the glacial to near-glacial intervals represented by the last glacial maximum and the Younger Dryas, and poorly ventilated during warm intervals of the Bølling/Allerød Interstadial and 


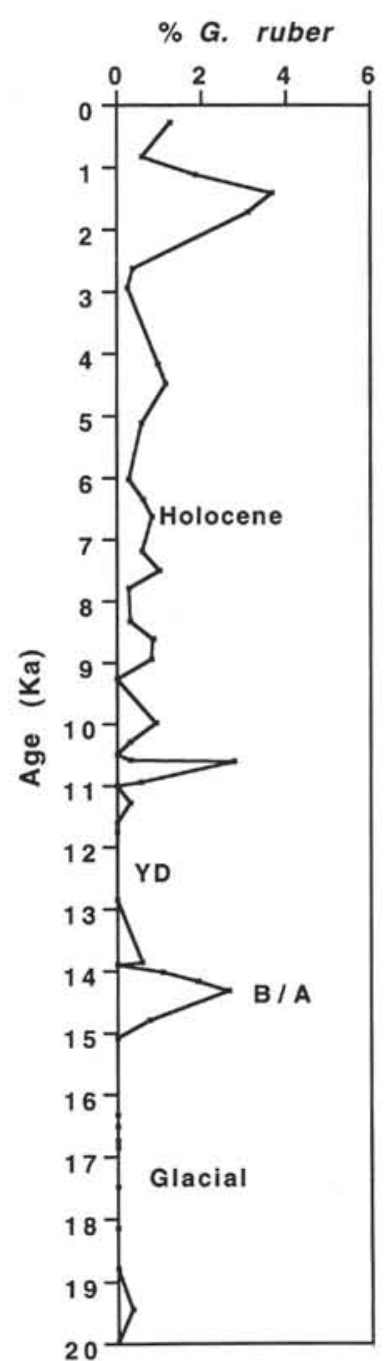

$\%$ N. dutertrei
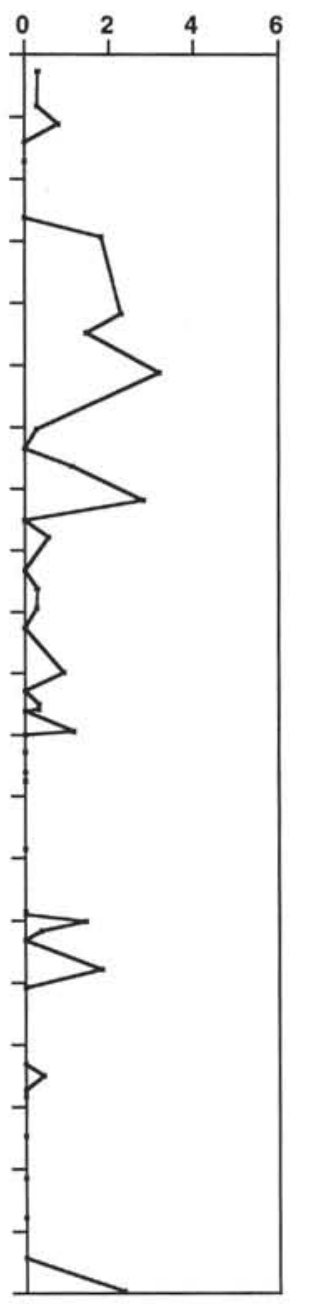

$\% G$

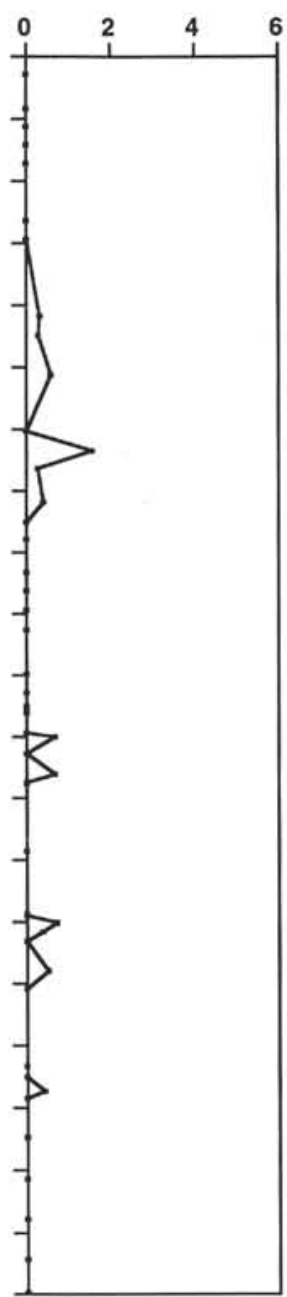

$\%$ o. universa
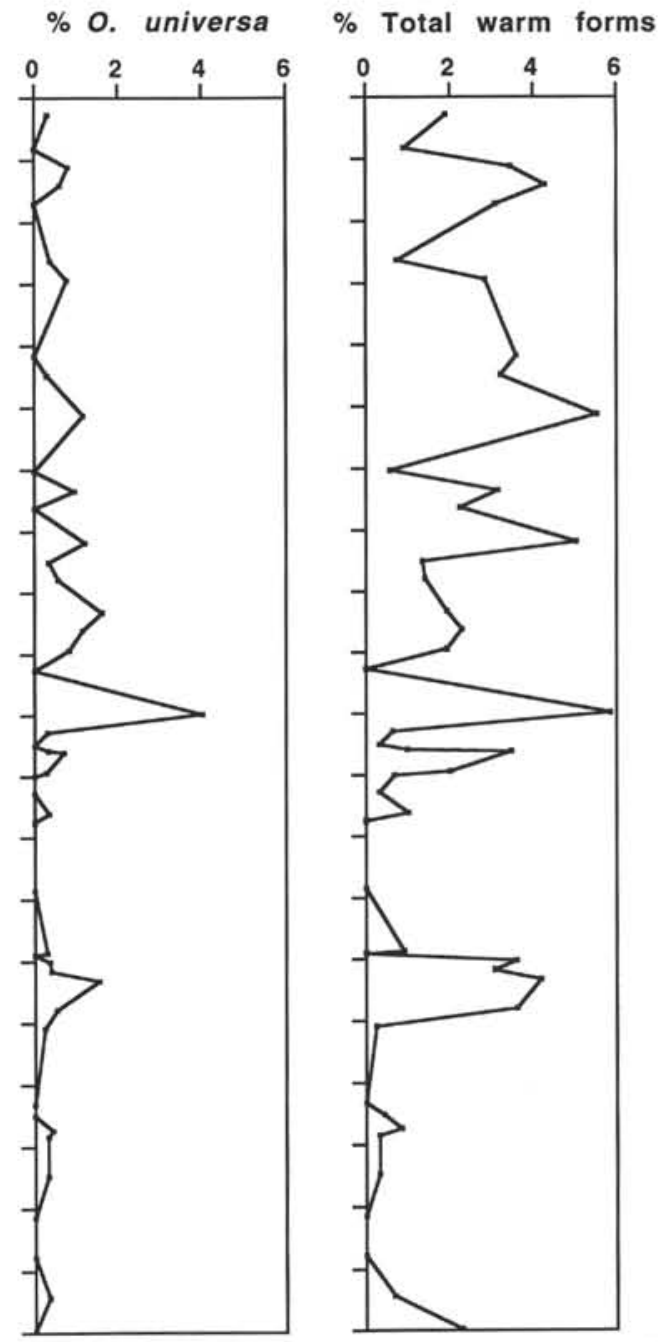

Figure 10. Percent frequency changes of Globigerinoides ruber. Neogloboquadrina dutertrei, Globorotalia inflata, and Orbulina universa and the sum of these percentages shown as total warm forms within planktonic foraminiferal assemblages during the last $20 \mathrm{k} . \mathrm{y}$. in Hole $893 \mathrm{~A}$. YD $=\mathrm{Younger}$ Dryas; $\mathrm{B} / \mathrm{A}=\mathrm{B} \emptyset \mathrm{lling} /$ Allerød.

the Holocene (last 11 k.y.). The ventilation shifts in the two basins almost certainly reflect changes in the source of intermediate waters entering the basins that were, in turn, modulated by global climate changes.

The climatically associated ventilation changes in Santa Barbara Basin also appear to be nearly synchronous with major changes in North Atlantic Deep Water (NADW) associated with climatic change (Schnitker, 1979; Boyle and Keigwin, 1982; Curry and Lohmann, 1983; Duplessy et al., 1988). Santa Barbara Basin was relatively well ventilated during the last glacial maximum and the Younger Dryas when NADW production was reduced (Boyle and Keigwin, 1987; Broecker et al., 1990; Birchfield and Broecker, 1990; Keigwin et al., 1991; Lehman and Keigwin, 1992) and/or when its southward flow through the Atlantic was at shallower depths (Rahmstorf, 1994; Boyle and Weaver, 1994; Boyle, in press). Conversely, when the flux of NADW was high during the Holocene and Bølling/Allerød warm intervals (Boyle and Keigwin, 1982) and/or when it flowed at greater depths (Rahmstorf, 1994; Boyle and Weaver, 1994), the basin was poorly ventilated. The view that cooling during the last glacial maximum and the Younger Dryas resulted in decreased production of NADW (Boyle and Keigwin, 1987) was challenged by Fairbanks
(1989) and Jansen and Veum (1990), but later countered by Keigwin et al. (1991).

Thermohaline processes associated with the conveyor supply large amounts of heat to the atmosphere over the North Atlantic region (Broecker et al., 1985) with resulting climatic warmth when conveyor circulation was more vigorous. It appears that the production of NADW is closely linked with changes in the stability of the water column due to salinity changes and interruption of North Atlantic heat flux (Rooth, 1982, 1990; Broecker et al., 1988: Keigwin et al., 1991). Deepwater formation in the northern Atlantic depends critically on the salinity of surface waters. Salinity of surface waters changes as a result of a number of mechanisms including changes in the flux rates of meltwater emanating from the Laurentide and Scandinavian ice sheets (Broecker, 1990). Interaction among the various processes changed the strength of the conveyor. Oscillations in conveyor strength resulted from the effect of changing ocean heat flux on the melting rate of the nearby ice sheets (Broecker et al., 1990; Birchfield and Broecker, 1990). Thus, intervals of increased production of NADW led to accelerated melting of the Fennoscandian ice sheet, which in turn tended to reduce vertical circulation and NADW production due to increased meltwater flux. The reduction in thermoha- 


\section{Dissolved Oxygen}

$\mathrm{mL} / \mathrm{L}$

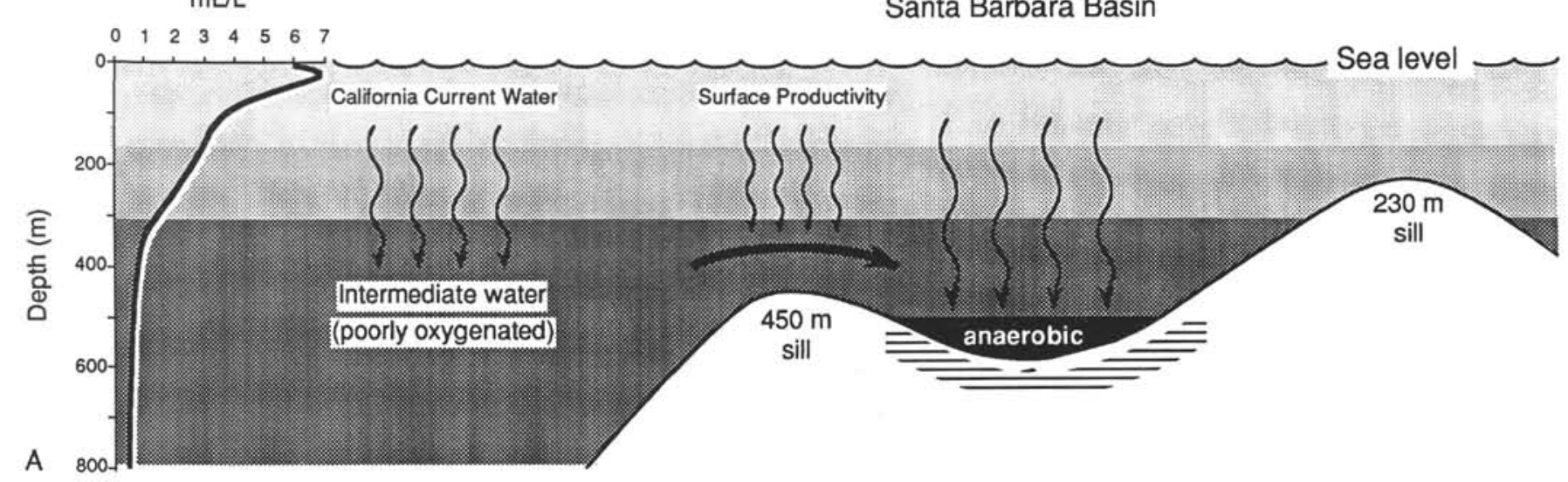

Santa Barbara Basin

\section{Dissolved Oxygen} $\mathrm{mL} \mathrm{L}$

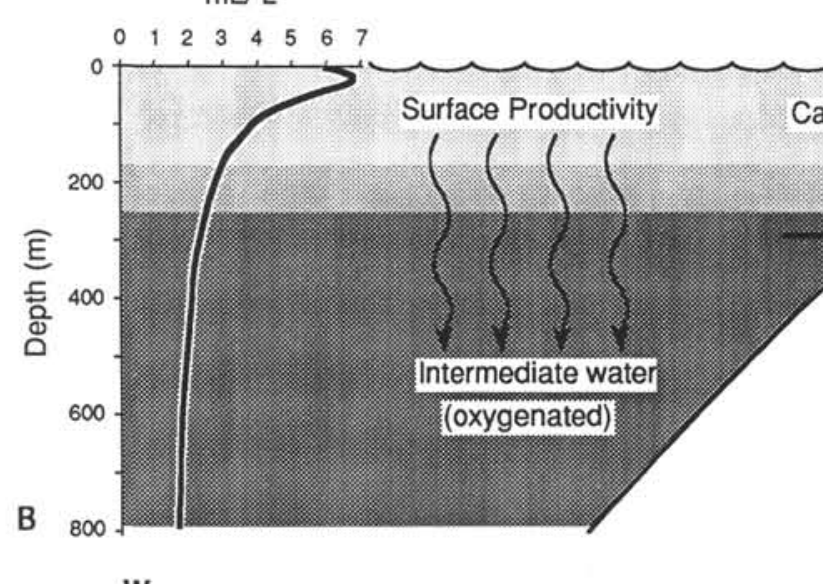

\section{Santa Barbara Basin}

California Current Water

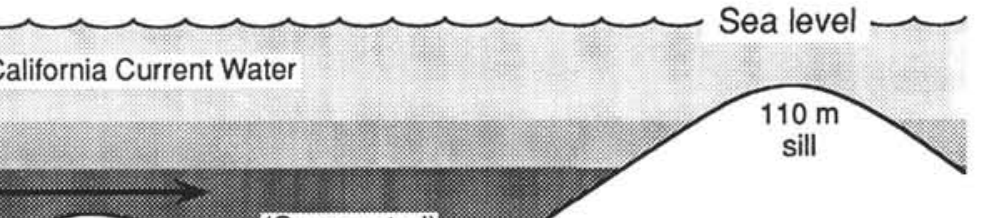

sill

Figure 11. Schematic diagrams showing differences in water mass distributions in the Santa Barbara Basin area between interstadial and interglacial intervals such as (A) the present day and (B) glacial to near-glacial intervals. Although features such as sea level changed between glacial and interglacial episodes, distinctive changes in the ventilation of Santa Barbara Basin between glacial and interglacial times were caused primarily by changes in the oxygen content of intermediate waters from the Pacific, as discussed in the text.

line circulation led to cooling, which reduced melting of the ice sheets, in turn led to an increased surface water salinity which renewed the production of NADW (Broecker, 1990; Lehman and Keigwin, 1992). The brief reduction in NADW production inferred during Younger Dryas cooling is explained within this framework (Broecker, 1990). Rapid ice sheet melting during deglaciation before the Younger Dryas reduced salinity of the Atlantic and diversion of meltwaters from the Gulf of Mexico to the northern Atlantic (Kennett and Shackleton, 1975; Broecker et al., 1989; Kennett, 1990; Flower and Kennett, 1990) triggered a shutdown of NADW production at the beginning of the Younger Dryas. The shutdown of NADW export and lowered meltwater flow to the northern Atlantic due to Younger Dryas cooling led to increased surface water salinity at high latitudes and renewed production of NADW at the end of the Younger Dryas (Broecker, 1990).

It appears, therefore, that the changes associated with the Younger Dryas (and the glacial-interglacial transition) seem to be representative of a self-sustaining circulation loop that is part of the larger scale water mass exchange between the North Atlantic and the rest of the world oceans (Zahn, 1992). Limited evidence from the deep-sea record outside of the North Atlantic suggests that during glaciations the pattern of flow was different in the Pacific and Indian Oceans as well as the Atlantic (Broecker and Denton, 1989) compared with the present day. Studies of carbon isotopic distribution in deep-sea cores suggests that during the last glaciation, waters at intermediate depths in the Indian Ocean (Kallel et al., 1988) and the Pacific (Duplessy et al., 1988) were relatively low in nutrients. Nutrient-depleted waters are expected to be richer in dissolved oxygen (Boyle, 1988). Two modes of oceanic circulation seem to have existed, with the Atlantic and Pacific becoming more similar in glacial time (Broecker et al., 1985).

The stratigraphic records indicate that the switches between the modes were closely synchronized between the North Pacific and the North Atlantic. Thus, a fundamental question has emerged as to the mechanism(s) involved that caused near-synchronous paleoceanographic changes between the two oceans. We consider three main hypotheses.

The first hypothesis is that Santa Barbara and Guaymas Basin sequences may record oscillations in the strength of thermohaline circulation originating as NADW at high latitudes of the North Atlantic-the so-called oceanic conveyor circulation (Broecker and Denton, 1989; Broecker, 1990). NADW flows southward at $\sim 3 \mathrm{~km}$ in the Atlantic to be entrained in eastward-flowing Circumpolar Water. Much of the water entering the circumpolar system leaves as north- 
ward-flowing deep waters to the North Pacific, where some fraction advects upwards and returns via surface routes to the North Atlantic. The flow of water within the conveyor from the North Atlantic to North Pacific takes $\sim 1000 \mathrm{yr}$. At time of formation, NADW is nutrient-poor and oxygen-rich because of its origin at the ocean surface. During transit within the conveyor, the progressively aging waters become nutrient-rich and oxygen poor. Systematic decrease in $\Delta^{14} \mathrm{C}$ occurs along the path of deep waters derived from the North Atlantic (Broecker and Peng, 1982). The greater age of basinal waters during the warmer intervals of the latest Quaternary, including the present day (Ingram and Kennett, this volume), may indicate the influence of the conveyor system on Pacific Intermediate Water. At the present time, the source of the oxygen-poor bottom waters in Santa Barbara and Guaymas Basins are derived from depths of the upper part of $\mathrm{Pa}$ cific Intermediate Water. However, Pacific Intermediate Water is believed to be depleted in $\Delta^{14} \mathrm{C}$ due to a large component of NADW (Broecker and Peng, 1982). Water entering Santa Barbara Basin over the sill has a radiocarbon age of 1200 to $1300 \mathrm{yr}$ (Ostlund and Stuiver, 1980) compared with 825 yr for the surface mixed layer, which is a mix of California Current and upwelled Pacific Intermediate Water (Ingram and Kennett, this volume). Water as old as $1980 \mathrm{yr}$ has been reported at depths of $\sim 3000 \mathrm{~m}$ in the North Pacific (Broecker and Peng, 1982).

This hypothesis suggests that weakening of the oceanic conveyor during cooler intervals would result in the replacement of Santa Barbara basinal waters by intermediate waters produced within the $\mathrm{Pa}$ cific Ocean. At these times younger, more oxygenated upper intermediate waters from more proximal sources would enter Santa Barbara and Guaymas basins. If this hypothesis is correct, the absence of any significant lag between the paleoceanographic changes in the North Atlantic and North Pacific implies that changes must be transmitted rapidly along the length of the conveyor. Since the conveyor flows through the circumantarctic current, potential relations between changes in the north Pacific and Atlantic are indirect. Therefore, the sedimentary changes we have described may be more a reflection of the changing strength of intermediate waters formed in the northwest Pacific. This region is considered to be the modern source for Pacific Intermediate Water (Reid, 1965, 1973; Talley, 1991, 1993).

The second hypothesis is that the inter-ocean paleoceanographic changes were linked directly via global climate change transmitted through the atmosphere rather than through changes in the strength of the oceanic conveyor. In this case, severe cooling during the last glacial maximum and the Younger Dryas episode, led to the production of intermediate waters at high latitudes in the Pacific Ocean. Of proximal origin, these were young, well-oxygenated waters. It is possible that intense cooling in the northwest Pacific may have led to the production of intermediate waters that influenced the northeast Pacific coast margin (Keigwin, 1987; Keigwin et al., 1992; Ohkouchi et al., 1994). Limited evidence for such water during glacial episodes is summarized by Keigwin et al. (1992). The absence of any significant lag between the paleoceanographic changes in the North Pacific and North Atlantic and their close association with climate change may favor this hypothesis, although it is unknown how rapidly changes in the flux of NADW may be transmitted along the oceanic conveyor. Although rapid propagation $(<1000$ years) has been inferred from deep-sea cores of deglacial-caused isotopic signals from the North Atlantic to the North Pacific (Duplessy et al., 1991), these are still slower than suggested in latest Quaternary record of Hole 893A.

A third, and more likely, hypothesis is that both factors in combination played a role in influencing the ventilation history of the basins. No matter which hypothesis is correct, the stratigraphic record strongly indicates that fundamental changes occurred in North Pacific paleoceanographic conditions during the latest Quaternary. These were closely synchronized with global climate change and with paleoceanographic events in the North Atlantic. Our work indicates the existence of tight coupling between changes in the atmosphereocean-cryosphere during the latest Quaternary.

\section{CONCLUSIONS}

I. The paleoclimatic record since $20 \mathrm{ka}$ has been examined at high resolution for Hole 893A, Santa Barbara Basin, using the oxygen isotopic history of benthic and planktonic foraminifers and quantitative changes in planktonic foraminiferal assemblages. A series of AMS ${ }^{14} \mathrm{C}$ dates provides a high-resolution chronology.

2. The record from Hole $893 \mathrm{~A}$ is an accurate representation of latest Quaternary global climate change including the last 20 k.y. The last deglaciation is recorded as two main steps (Termination IA and IB) separated by a warm pause correlative with the Bølling/Allerød Interstadial (15.2 to $13 \mathrm{ka}$ ), followed by Younger Dryas cooling (13 to $11.2 \mathrm{ka}$ ).

3. Changes in planktonic foraminiferal assemblages suggest that average sea-surface temperatures in Santa Barbara Basin increased from $\sim 7^{\circ}-8^{\circ} \mathrm{C}$ during the last glacial maximum to $\sim 15^{\circ} \mathrm{C}$ during the late Holocene, an increase of $\sim 7^{\circ}-8^{\circ} \mathrm{C}$. Oxygen isotopic changes in planktonic foraminifers indicate seasurface temperature variations (from $20-30 \mathrm{yr}$ averaged samples) of $<3^{\circ} \mathrm{C}$ during the Holocene.

4. Hole $893 \mathrm{~A}$ is represented by an alternation of intervals dominated by laminated and nonlaminated (massive) sediments. Laminated intervals were deposited at times of low dissolvedoxygen levels in the basin that precluded support of an active benthos. Massive intervals resulted from bioturbation associated with more oxygenated basinal waters. The sequence exhibits a strong correlation between major climate changes during the last $20 \mathrm{k} . \mathrm{y}$. and the boundaries between dominantly laminated and massive intervals.

5. The basin was relatively well oxygenated during the glacial to near-glacial intervals represented by the last glacial maximum and the Younger Dryas cooling, and poorly oxygenated during warm intervals of the Bølling/Allerød Interstadial and the Holocene during the last $11 \mathrm{k} . \mathrm{y}$. These represent oscillations between two fundamentally different ocean states, one marked by waters with low oxygen content associated with warm intervals, and the other with relatively oxygenated waters associated with cold intervals.

6. Latest Quaternary oscillations in basinal sediment facies reflect changes in the source of intermediate waters, with greater proportion originating from a more proximal source during cooler intervals compared with a distal source during warmer intervals, including the present day.

7. The stratigraphic records examined here strongly indicate that, as in the North Atlantic, fundamental changes occurred in intermediate water circulation in the North Pacific during the latest Quaternary. These were closely synchronized with global climate change and with paleoceanographic events in the North Atlantic associated with the changing strength of NADW production and oceanic conveyor circulation. The absence of any significant lags between the ventilation history and climate changes indicates a tight coupling has existed between changes in the atmosphere-ocean-cryosphere during the latest Quaternary.

8. The climatically related major changes in oxygenation in Santa Barbara Basin took place in less than a few decades, implying the existence of threshold levels in the climate system.

\section{ACKNOWLEDGMENTS}

This research was supported by JOI/USSAC grant Texas A\&M USSP008 and National Science Foundation Grants EAR-92-04857 (Earth Sciences) and DPP92-18720 (Polar Programs). We thank Karen Thompson, Staci Richard, and Howard Berg for their laboratory support. We also thank Ellen Kappel for her support and encouragement. Rick Behl, Ed Boyle, Lloyd Keigwin, Mitch Lyle, and Ted 
Moore provided valuable advice and constructive criticism of the manuscript. The research of BLI was supported in part by an appointment to the Global Change Distinguished Postdoctoral Fellowships, sponsored by the U.S. Department of Energy, Office of Health and Environmental Research, and administered by the Oak Ridge Institute for Science and Education. We thank M. Kashgarian and J. Southon at CAMS for discussions and assistance in radiocarbon analyses. Thanks are also extended to Greg Blake and UNOCAL Corporation for financial support. The Ocean Drilling Program has continued to play a key role in fostering this research.

\section{REFERENCES}

Alley, R.B., Kapsner, W.R., Shuman, C., and Anandakrishnan, S., Finkel, R.C., Gow, A.J., Grootes, P.M., Mayewski, P.A., Meese, D.A., Nishiizumi, K., and Waddington, E.D., 1993a. Clues to the Younger Dryas from accumulation-rate measurements in the GISP2 ice core. Eos, 74 (Suppl.):79. (Abstract)

Alley, R.B., Meese, D.A., Shuman, C.A., Gow, A.J., Taylor, K.C., Grootes, P.M., White, J.W.C., Ram, M., Waddington, E.D., Mayewski, P.A., and Zielinski, G.A., 1993b. Abrupt increase in Greenland snow accumulation at the end of the Younger Dryas event. Nature, 362:527-529.

Atkinson, L.P., Brink, K.H., Davis, R.E., Jones, B.H., Paluszkiewicz, T., and Stuart, D.W., 1986. Mesoscale hydrographic variability in the vicinity of Points Conception and Arguello during April-May 1983: the OPUS 1983 experiment. J. Geophys. Res., 91:12899-12918.

Bakun, A., 1975. Daily and weekly upwelling indices, west coast of North America, 1967-1973. Natl. Oceanic Atmos. Adm. (U.S.), Spec. Sci. Rep.-Fish., 693.

Bandy, O.L., 1968. Paleoclimatology and Neogene planktonic foraminiferal zonation. G. Geol., 35:277-290.

Bard, E., Arnold, M., Fairbanks, R.G., and Hamelin, B., 1993. ${ }^{230} \mathrm{Th}-{ }^{234} \mathrm{U}$ and ${ }^{14} \mathrm{C}$ ages obtained by mass spectrometry on corals. Radiocarbon, $35: 191-199$.

Bard, E., Hamelin, B., Fairbanks, R.G., and Zinder, A., 1990a. Calibration of the ${ }^{14} \mathrm{C}$ time-scale over the past 30,000 years using mass spectrometric U-Th ages from Barbados corals. Nature, 345:405-410.

.1990b. U/Th and ${ }^{14} \mathrm{C}$ ages of corals from Barbados and their uses for calibrating the ${ }^{14} \mathrm{C}$ timescale beyond 9000 years BP. In Yiou, F., and Raisbeck, G. (Eds.), Proc. 5th Int. Conf. Accel. Mass Spectrom. Nuclear Instruments and Methods, B52. Amsterdam (North-Holland), 461-468.

Birchfield, G.E., and Broecker, W.S., 1990. A salt oscillator in the glacial Atlantic? 2. A "Scale Analysis" model. Paleoceanography, 5:835-843.

Boyle, E., and Weaver, A., 1994. Conveying past climates. Nature, 372:4142.

Boyle, E.A., 1988. Cadmium: chemical tracer of deepwater paleoceanography. Palaeoceanography, 3:471-490.

Boyle, E.A., in press. Last glacial maximum North Atlantic Deep Water: on, off, or somewhere in-between? Proc. R. Soc, London.

Boyle, E.A., and Keigwin, L.D., 1982. Deep circulation of the North Atlantic over the last 200,000 years: geochemical evidence. Science, 218:784 787.

, L.D., 1987. North Atlantic thermohaline circulation during the past 20,000 years linked to high-latitude surface temperature. Nature, 330:35-40.

Broecker, W.S., 1990. Salinity history of the Northern Atlantic during the last deglaciation. Paleoceanography, 5:459-467.

Broecker, W.S., Bond, G., and Klas, M., 1990. A salt oscillator in the glacial Atlantic? 1. The concept. Paleoceanography, 5:469-477.

Broecker, W.S., and Denton, G.H., 1989. The role of ocean-atmosphere reorganization in glacial cycles. Geochim. Cosmochim. Acta, 53:2465-2501.

Broecker, W.S., Kennett, J.P., Flower, B.P., Teller, J.T., Trumbore, S., Bonani, G., and Wolfli, W., 1989. Routing of meltwater from the Laurentide ice sheet during the Younger Dryas cold episode. Nature, 341:318321.

Broecker, W.S., Oppo, D., Peng, T.-H., Curry, W., Andree, M., Wolfli, W., and Bonani, G., 1988. Radiocarbon-based chronology for the ${ }^{18} \mathrm{O} /{ }^{16} \mathrm{O}$ record for the last deglaciation. Paleoceanography, 3:509-515.

Broecker, W.S., and Peng, T.-H., 1982. Tracers in the Sea: Palisades, NY (Lamont-Doherty Geological Observatory).

Broecker, W.S., Peteet, D.M., and Rind, D.H., 1985. Does the ocean-atmosphere system have more than one stable mode of operation? Nature, $315: 21-26$.
Craig, H., 1957. Isotopic standards for carbon and oxygen and correction factors for mass-spectrometric analysis of carbon dioxide. Geochim. Cosmochim. Acta, 12:133-149.

Curry, W.B., and Lohmann, G.P., 1983. Reduced advection into Atlantic Ocean deep eastern basins during last glaciation maximum. Nature, 306:577-580.

Denton, G.H., and Hendy, C.H., 1994. Younger Dryas age advance of Franz. Josef Glacier in the Southern Alps of New Zealand. Science, 264:1434 1437.

Douglas, R., 1981. Paleoecology of continental margin basins: a modern case history from the borderland of Southern California. In Douglas, R., Gorsline, D., and Colburn, L. (Eds.), Depositional Systems of Active Continental Margin Basins. Soc. Econ. Paleontol. Mineral., Pacific Sect., Short Course, 121-156.

Dunbar, R.B., 1983. Stable isotope record of upwelling and climate from Santa Barbara Basin, California. In Thiede, J., and Suess, E. (Eds.), Coastal Upwelling, its Sediment Record, Part B. Sedimentary Records of Ancient Coastal Upwelling: New York (Plenum), 217-246.

Duplessy, J.C., 1989. Global changes during the last 20,000 years: the ocean sediment record. In Bradley, R.S. (Ed.), Global Changes of the Past: Boulder, CO (Interdiscip. Earth Stud.), 341-355.

Duplessy, J.C., Bard, E., Arnold, M., Shackleton, N.J., Duprat, J., and Labeyrie, L., 1991. How fast did the ocean-atmosphere system run during the last deglaciation? Earth Planet. Sci. Lett., 103:27-40.

Duplessy J.-C., Shackleton, N.J., Fairbanks, R.G., Labeyrie, L., Oppo, D., and Kallel, N., 1988. Deep-water source variations during the last climatic cycle and their impact on global deepwater circulation. Paleoceanography, 3:343-360.

Edwards, R.L., Beck, J.W., Burr, G.S., Donahue, D.J., Chappell, J.M.A., Bloom, A.L., Druffel, E.R.M., and Taylor, F.W., 1993. A large drop in atmospheric ${ }^{14} \mathrm{C}^{12} \mathrm{C}$ and reduced melting in the Younger Dryas, documented with ${ }^{230} \mathrm{Th}$ ages of coral. Science, 260:962-968.

Emery, K.O., 1960. The Sea off California: A Modern Habitat of Petroleum: New York (Wiley).

Enfield, D.B., and Allen, J., 1980. On the structure and dynamics of monthly mean sea level anomalies along the Pacific Coast of North and South America. J. Phys. Oceanogr., 10:557-578.

Eppley, R.W. (Ed.), 1986. Plankton dynamics of the Southern California Bight. Lect. Notes Coastal Estuarine Stud., 15.

Fairbanks, R.G., 1989. A 17,000-year glacio-eustatic sea level record: influence of glacial melting rates on the Younger Dryas event and deep-ocean circulation. Nature, 342:637-642.

Flower, B.P., and Kennett, J.P., 1990. The Younger Dryas cool episode in the Gulf of Mexico. Paleoceanography, 5:949-961.

Gardner, J.V., Heusser, L.E., Quinterno, P.J., Stone, S.M., Barron, J.A., and Poore, R.Z., 1988. Clear Lake record vs. the adjacent marine record: a correlation of their past 20,000 years of paleoclimatic and paleoceanographic responses. In Sims, J.D. (Ed.), Late Quaternary Climate, Tectonism, and Sedimentation in Clear Lake, Northern California Coast Ranges. Spec. Pap.-Geol. Soc. Am., 214:171-182.

Gray, S.C., Burr, G.S., Donahue, D.J., Edwards, R.L., Taylor, F.W., Recy, J., and Cabioch, G., 1993. Comparison of TIMS ${ }^{230} \mathrm{Th}$ and ${ }^{14} \mathrm{C}$ ages of Pacific corals for the last deglaciation: evidence for a rapid oscillation of $\delta^{14}$ C. Eos, $74: 328$.

Heusser, L.E., 1978. Marine pollen in Santa Barbara Basin, California: a 12,000-yr record. Geol. Soc. Am. Bull., 89:673-678.

Heusser, L.E., and Shackleton, N.J., 1979. Direct marine-continental correlation: 150,000-year oxygen isotope-pollen record from the North Pacific. Science, 204:837-839.

Hickey, B.M., 1992. Circulation over the Santa Monica-San Pedro Basin and Shelf. Prog. Oceanog., 30:37-115.

Jansen, E., and Veum, T., 1990. Evidence for two-step deglaciation and its impact on North Atlantic deep-water circulation. Nature, 343:612-616.

Johnson, S.J., Clause, H.B., Dansgaard, W., Fuhrer, K., Gundestrup, N., Hammer, C.U., Iversen, P., Jouzel, J., Stauffer, B., and Steffensen, J.P., 1992. Irregular glacial interstadials recorded in a new Greenland ice core. Nature, 359:311-313.

Kallel, N., Labeyrie, L.D., Arnold, M., Okada, H., Dudley, W.C., and Duplessy, J.-C., 1988. Evidence of cooling during the Younger Dryas in the western North Pacific. Oceanol. Acta, 11:369-375.

Karpuz, N.K., and Jansen, E., 1992. A high-resolution diatom record of the last deglaciation from the SE Norwegian Sea: documentation of rapid climatic changes. Paleoceanography, 7:499-520.

Keigwin, L.D., 1987. North Pacific deep water formation during the latest glaciation. Nature, 330:362-364. 
Keigwin, L.D., and Jones, G.A., 1990. Deglacial climatic oscillations in the Gulf of California. Paleoceanography, 5:1009-1023.

Keigwin, L.D., Jones, G.A., and Froelich, P.N., 1992. A 15,000 year paleoenvironmental record from Meiji Seamount, far northwestern Pacific. Earth Planet. Sci. Lett., 111:425-440.

Keigwin, L.D., Jones, G.A., and Lehman, S.J., and Boyle, E.A., 1991. Deglacial meltwater discharge, North Atlantic deep circulation, and abrupt climate change. J. Geol. Res., 96(NC9):16811-16826.

Kennett, J.P., 1990. The Younger Dryas cooling event: an introduction. Paleoceanography, 5:891-895.

Kennett, J.P., Baldauf, J.G., et al., 1994. Proc. ODP, Init. Repts., 146 (Pt. 2): College Station, TX (Ocean Drilling Program).

Kennett, J.P., and Shackleton, N.J., 1975. Laurentide Ice Sheet meltwater recorded in Gulf of Mexico deep-sea cores. Science, 188:147-150.

Lange, C.B., Berger, W.H., Burke, S.K., Casey, R.E., Schimmelmann, A., Soutar, A., and Weinheimer, A.L., 1987. El Niño in Santa Barbara basin diatom, radiolarian, and foraminiferan responses to the "1983 El Niño" event. Mar. Geol., 78:153-160.

Lehman, S.J., and Keigwin, L.D., 1992. Sudden changes in North Atlantic circulation during the last deglaciation. Nature, 356:757-762.

Lyle, M., Zahn, R., Prahl, F., Dymond, J., Collier, R., Pisias, N., and Suess, E., 1992. Paleoproductivity and carbon burial across the California Current: the Multitracers Transect, $42^{\circ} \mathrm{N}$. Paleoceanography, 7:251-272.

Mathewes, R.W., Heusser, L.E., and Patterson, R.T., 1993. Evidence for a Younger Dryas-like cooling event on the British Columbia coast. Geology, 21:101-104.

McGowan, J.A., 1984. The California El Niño, 1983. Oceanus, 27:48-51.

Moore, T.C., 1973. Late Pleistocene-Holocene oceanographic changes in the northeastern Pacific. Quat. Res., 3:99-109.

Namias, J., 1969. Use of sea-surface temperature in long-range predictions. WMO Technical Note 103. In Sea-Surface Temperatures. World Meteorological Organization, 247:1-18.

Ohkouchi, N., Kawahate, H., Murayama, M., Okada, M., Nakamura, T., and Taira, A., 1994. Was deep water formed in the North Pacific during the Late Quaternary? Cadmium evidence from the northwest Pacific. Earth Planet. Sci. Lett., 124:185-194.

Ostlund, H.G., and Stuiver, M., 1980. GEOSECS Pacific radiocarbon. Radiocarbon, 22:25-53.

Pisias, N.G., 1978. Paleoceanography of the Santa Barbara Basin during the last 8000 years. Quat. Res., 10:366-384.

1979. Model for paleoceanographic reconstructions of the California Current during the last 8000 years. Quat. Res., 11:373-369.
Rahmstorf, S., 1994. Rapid climate transitions in a coupled ocean-atmosphere model. Nature, 372:82-85.

Reid, J.L, 1965. Intermediate Waters of the Pacific Ocean: Baltimore (Johns Hopkins Press). , 1973. Northwest Pacific Ocean Waters in Winter: Baltimore (John Hopkins Press).

Rooth, C., 1982. Hydrology and ocean circulation. Prog. Oceanog., 11:131149.

1990. Meltwater Younger Dryas upheld. Nature, 343:702.

Sancetta, C., Lyell, M., Heusser, L., Zahn, R., and Bradbury, J.P., 1992. Late-glacial to Holocene changes in winds, upwelling, and seasonal production of the Northern California current system. Quat. Res., 38:359370.

Savrda, C.E., Bottjer, D.J., and Gorsline, D.S., 1984. Development of a comprehensive oxygen-deficient marine biofacies model: evidence from Santa Monica, San Pedro and Santa Barbara basins, California Continental Borderland. AAPG Bull., 68:1179-1192.

Schimmelmann, A., and Tegner, M.J., 1991. Historical oceanographic events reflected in ${ }^{13} \mathrm{C} /{ }^{12} \mathrm{C}$ ratio of total organic carbon in Santa Barbara basin sediment. Global Biogeochem. Cycles, 5:173-188.

Schnitker, D., 1979. The deep waters of the western North Atlantic during the past 24,000 years, and the re-initiation of the western boundary undercurrent. Mar. Micropaleontol., 4:265-280.

Soutar, A., and Crill, P.A., 1977. Sedimentation and climatic patterns in the Santa Barbara Basin during the 19th and 20th centuries. Geol. Soc. Am. Bull., 88:1161-1172.

Stuiver, M., and Braziunas, T.F., 1993. Modeling atmospheric ${ }^{14} \mathrm{C}$ influences and ${ }^{14} \mathrm{C}$ ages of marine samples to 10,000 BC. Radiocarbon, 35:137-189.

Talley, L.D., 1991. An Okhotsk sea water anomaly: implications for ventilation in the North Pacific. Deep-Sea Res., 38 (Suppl.):5171-5190.

1993. Distribution and formation of North Pacific intermediate water. J. Phys. Oceanogr., 23:517-537.

Weinheimer, A.L., Carson, T.L., Wigley, C.R., and Casey, R.E., 1986. Radiolarian responses to recent and Neogene California El Niño and anti-El Niño events. Palaeogeogr., Palaeoclimatol., Palaeoecol., 53:3-25.

Zahn, R., 1992. Deep ocean circulation puzzle. Nature, 356:744-746.

Date of initial receipt: 2 September 1994

Date of acceptance: 13 February 1995

Ms 146SR-296 